

\begin{tabular}{|c|c|}
\hline REPORT DOCUMENTATION PAGE & $\begin{array}{l}\text { READ NNSTRUCTIONS } \\
\text { BEFORE COMPLETING FORM }\end{array}$ \\
\hline \begin{tabular}{|l|l|} 
2. GOVT ACCESSION NO. \\
\end{tabular} & 3. RECIPIENT'S CATALOG NUMBER \\
\hline \multirow{2}{*}{$\begin{array}{l}\text { 4. TITLE (end Subtitı) } \\
\text { COLD WEATHER CONSTRUCTION MATERIALS } \\
\text { PART 1: REGULATED-SET CEMENT FOR COLD WEATHER } \\
\text { CONCRETING }\end{array}$} & 5. TYPE OF REPORT \& PERIOD COVERED \\
\hline & $\begin{array}{l}\text { 6. PERFORMING ORG. REPORT NUMBER } \\
\text { Miscellaneous Paper C-75-11 }\end{array}$ \\
\hline $\begin{array}{l}\text { 7. AUTHOR(o) } \\
\text { B.J. Houston and G.C. Hoff }\end{array}$ & $\begin{array}{l}\text { 8. CONTRACT OR GRANT NUMBER(०) } \\
\text { Inter-Army Nos. CRREL 73-23 and } \\
\text { CRREL 74-17 }\end{array}$ \\
\hline $\begin{array}{l}\text { 9. PERFORMING ORGANIZATION NAME AND ADDRESS } \\
\text { U.S. Army Engineer Waterways Experiment Station (WES) } \\
\text { Vicksburg, Mississippi }\end{array}$ & $\begin{array}{l}\text { 10. PROGRAM ELEMENT.PROJECT, TASK } \\
\text { AREA \& WRK UNIT NUMBERS } \\
\text { DA Project 4K078012AAM1 } \\
\text { Task } 00 \text { Work Unit } 004\end{array}$ \\
\hline \multirow{2}{*}{$\begin{array}{l}\text { 11. CONTROLLING OFFICE NAME AND ADDRESS } \\
\text { Directorate of Military Construction } \\
\text { Office, Chief of Engineers } \\
\text { Washington, D.C. } 20314\end{array}$} & $\begin{array}{l}\text { 12. REPORT DATE } \\
\text { December } 1975\end{array}$ \\
\hline & $\begin{array}{l}\text { 13. NUMBER OF PAGES } \\
27\end{array}$ \\
\hline \multirow[t]{2}{*}{$\begin{array}{l}\text { 14. MONITORING AGENCY NAME ADDRESS(If dilforent trom Controlline Offtco) } \\
\text { U.S. Army Cold Regions Research and Engineering Laboratory } \\
\text { Hanover, N.H. } 03755\end{array}$} & $\begin{array}{l}\text { 15. SECURITY CLASS. (of thle report) } \\
\text { Unclassified }\end{array}$ \\
\hline & $\begin{array}{l}\text { 15a. DECLASSIFICATION/DOWNGRADING } \\
\text { SCHEDULE }\end{array}$ \\
\hline
\end{tabular}

\section{DISTRIBUTION STATEMENT (Of thla Roport)}

Approved for public release; distribution unlimited.

17. DISTRIBUTION STATEMENT fof the abatract ontored in Block 20, if difforent from Report)

18. SUPPLEMENTARY NOTES

19. KEY WORDS fCominue on reveres ofde if necessary and identlfy by block number)

Cold regions

Construction

Regulated-set concrete

20. ABSTRACT (Contlnue on reverue dide If neceenary and Idontlfy by block number)

The U.S. Army carries on construction projects in localities such as Alaska, the northern tier of the United States, northern Europe, Greenland and other arctic sites where the concrete placing season is shortened considerably by the cold climate. At ambient temperatures below $50^{\circ} \mathrm{F}$, concreting operations become considerably more expensive since U.S. Army Corps of Engineers specifications require freshly mixed and placed concrete to be protected from ambient temperatures. This report covers part of an investigation to locate and evaluate existing and new cementing materials that allow concrete to be placed at ambient temperatures as low as $15^{\circ} \mathrm{F}$. A newly developed cement termed "regulated-set" cement, which is an accelerated set cement, appeared to have great promise and was selected for study 
in this stage of the investigation. Both mortars and concretes made with regulated-set cement were studied with the following results: 1 . The longer freshly mixed regulated-set cement concrete remains above freezing before exposure to below freezing temperatures the greater the subsequent early strength gain; however, considerable strength gain was exhibited by specimens exposed at $15^{\circ}$ immediately after casting. Specimens protected one hour before exposure exhibited almost as much strength at 28 days age as specimens cured at $70^{\circ} \pm 3^{\circ} \mathrm{F}$ for the full time. 2 . The heat development in 3-, 6- and 12-in.-thick slabs exposed at $15^{\circ} \mathrm{F}$ immediately after casting, peaked in one to two hours at $46.5^{\circ}, 58^{\circ}$ and $69^{\circ} \mathrm{F}$, respectively, and remained above freezing long enough to gain considerable strength. 3. The introduction of a retarder into the mixture caused an increase in slump and a 13 to $19 \%$ decrease in 28 -day strength in specimens exposed at both $70^{\circ} \pm 3^{\circ} \mathrm{F}$ and $15^{\circ} \mathrm{F}$. There was still considerable strength developed, however, in the specimens exposed at low temperatures. 


\section{PREFACE}

The work described in this report was conducted at the U.S. Army Engineer Waterways Experiment Station (WES), Vicksburg, Mississippi, under the direction of B. Mather, Chief, Concrete Laboratory, J.M. Polatty, Chief, Engineer and Mechanics Division, G.C. Hoff, Chief, Materials and Properties Branch, E.C. Roshore, Assistant Chief, Materials and Properties Branch, and B.J. Houston, Assistant Chief, Materials and Properties Branch. This project was performed at the request of the U.S. Army Cold Regions Research and Engineering Laboratory (USA CRREL) under the general guidance of Francis Sayles, Research Civil Engineer, Northern Engineering Research Branch, Experimental Engineering Division. The project was authorized by Inter-Army Order Nos. CRREL 73-23 (15 November 1972) and CRREL 74-17 (15 November 1973). This report was prepared by B.J. Houston and G.C. Hoff. Technical reviewers were Frederick E. Crory of USA CRREL and Francis Sayles.

The contents of this report are not to be used for advertising, publication, or promotional purposes. Citation of trade names does not constitute an official endorsement or approval of the use of such commercial products.

Manuscript received 9 July 1975. 


\section{CONTENTS}

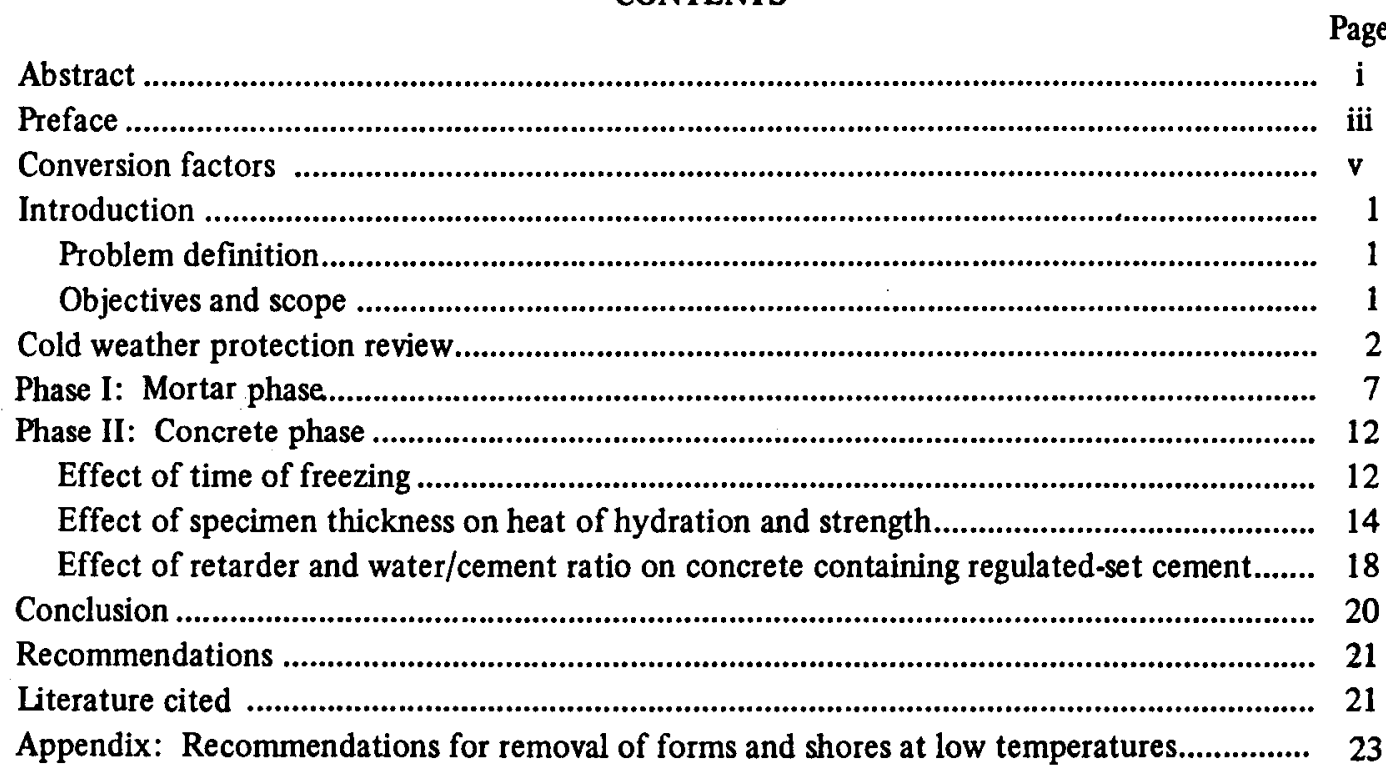

Figure

\section{ILLUSTRATIONS}

1. Effect of age of specimens when exposed to freezing temperature upon compressive strength

2. Effect of slab thickness on compressive strength ....................................................... 15

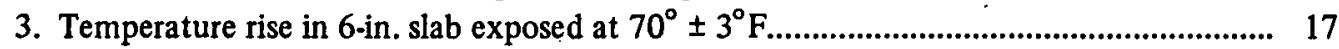

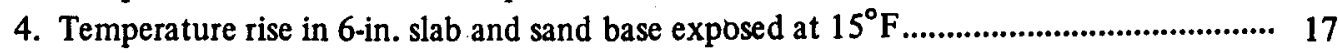

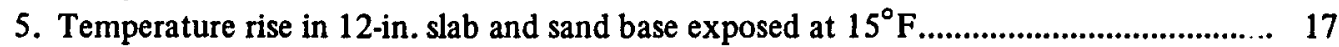

-6. Temperaturé rise in $\overline{\mathbf{a}} 3$-in. slab and ${ }^{-}$in sand base exposed at $15^{\circ} \mathrm{F}$................................. 18

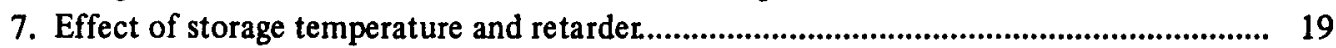

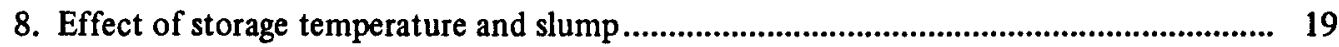

\section{TABLES}

Table

I. Times of protection recommended at minimum specified temperatures

II. Summary of U.S. Army Corps of Engineers guide specifications for nonarctic concrete construction

III. Guide specifications for concrete construction ................................................................ 5

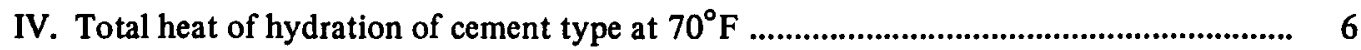

V. Mortar mixtures containing quick set cements ............................................................ 8

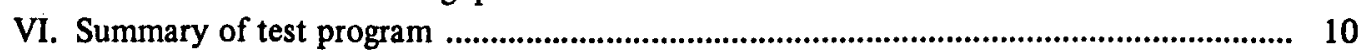

VII. Temperature, mixing proportions, and batching sequence......................................... 11

VIII. Results of Phase I .............................................................................................. 11

IX. Effect of time of low temperature exposure upon compressive strength.......................... 14

$X$. Compressive strength of cubes sawed from temperature study concrete slabs ................. 15

XI. Temperature rise in concrete slabs of various thicknesses and transfer of temperature to

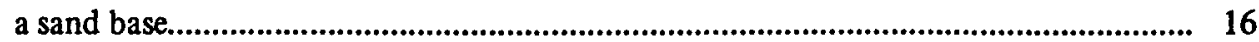

XII. Effect of retarder and slump on reg-set cement........................................................ 20 
CONVERSION FACTORS, ENGLISH TO SI UNITS

inches

feet

square leet

pounds

cubic yards

Fahrenheit degrees

pounds per cubic yard

pounds (force) per syuare inch
2.54
0.3048
0.092903
0.45359237
0.7645549
$5 / 9$
0.5932764
0.00689476

centimeters
meters
square meters
kilograms
cubic meters
Celsius degrees or Kelvins*
kilograms per cubic meter
megapascals

- To obtain Celsius (C) temperature readings from Fahrenheit (F) readings, use the following formula:

$C=(5 / 9)(F-32)$. To obtain Kelvin $(K)$ readings, use: $K=(5 / 9)(F-32)+273.15$. 


\title{
COLD WEATHER CONSTRUCTION MATERIALS \\ PART 1: REGULATED-SET CEMENT FOR COLD WEATHER CONCRETING
}

by

\author{
B.J. Houston and G.C. Hoff
}

INTRODUCTION

The U.S. Army carries on construction projects in many localities of varying climatic conditions. In many areas, the construction season is shortened considerably by unseasonal periods of cold weather in the spring or fall. The problems and proposed solutions associated with the mixing, placing, and curing of concrete in cold weather are well-known and documented, * but a permanent, universal solution has not been found. In arctic and subarctic areas, concreting must frequently be done at temperatures near and below freezing. Even in the Arctic, the placing of concrete at temperatures below $32^{\circ} \mathrm{F}$ is generally not practicable except for small projects or for extremely largescale operations with sizable plants. Concrete can thus be placed only during a short work season averaging one to two months in the Arctic and two to three months in most subarctic areas without protection against freezing. ${ }^{9}$ The minimum practicable temperature limit for concreting as viewed by various countries with long periods of cold weather varies from $23^{\circ} \mathrm{F}$ in Denmark to $-4^{\circ} \mathrm{F}$ in Sweden."

\section{Problem definition}

Some of the principal problems associated with winter concreting are protecting the freshly mixed concrete from freezing and providing a curing environment conducive to the development of sufficient strength in the concrete so that subsequent freezing and thawing will not damage it. If the concrete is kept sufficiently warm (above $32^{\circ} \mathrm{F}$ ) so that it does not freeze when made and placed, it will continue to develop strength with a rate of strength gain depending on the temperature at which it is cured. But maintaining above-freezing temperatures can present another problem. Concrete placed on permafrost but kept at temperatures greater than $32^{\circ} \mathrm{F}$ can cause melting of the underlying permafrost. Possible damage to the structure or element made with the concrete can thus occur, due to differential ground movements associated with the permafrost thawing.

A simultaneous solution to both the problems of concrete protection and permafrost protection is then not possible if hydraulic cements (those requiring water) as they presently exist today are used, and if the structures or elements made with the concrete are in direct contact with the permafrost.

\section{Objectives and scope}

The overall objective of the Cold Weather Construction Materials Project at USA WES is the evaluation of existing and new binder materials which can be used in concrete and concrete-like composites in cold weather environments. These materials should be able to be placed in the field at temperatures as low as $15^{\circ} \mathrm{F}$, and require a minimum of attention after placement. The specific

\footnotetext{
Refs. 1, 8-12, 16, 17, 19, 21 .
} 
topic of this report is the evaluation of regulated-set cement as a binder in concrete when the concrete is placed at low temperatures. This report includes a review of the cold weather protection criteria for portland cement concrete, a detailed description of the regulated-set cement used in this study, and the experimental work completed thes far in the project.

The experimental work described in this report was accomplished in two phases. Phase I (mortar phase) involved the evaluation of 41 mortar mixtures made at a number of different water/cement ratios and containing type III and regulated-set cements plus:four different admixtures. The materials were at different temperatures when batched, were mixed at three different temperatures, and were cured at two different temperatures. From evaluations of compressive strength and workability, one mixture was chosen as a suitable matrix for cold weather concrete.

Phase II (concrete phase) involved the development of a regulated-set cement concrete mixture for use at $15^{\circ} \mathrm{F}$. The mixture was evaluated for strength after immediate and delayed freezing and for the effect of section thickness on heat development and concrete strength.

\section{COLD WEATHER PROTECTION REVIEW}

The principal problem in cold weather protection consists of preventing loss of heat from concrete placed at a safe initial temperature and supplying any additional heat necessary for continued curing and strength development. If fresh concrete is frozen while there is considerable free water in the mixture, and the paste, as it goes from its liquid to solid phase, has not attained sufficient strength to resist the expansive forces associated with an increase in volume of the water, the internal structure of the concrete can be disrupted with corresponding decreases in strength. The 28-day compressive strength of concrete which has been frozen may be reduced to 30 to $50 \%$ of the strength of concrete which has not been frozen. ${ }^{15}$

How long should the concrete be protected from freezing? The duration of protection required to develop strength will vary with the conditions under which the concrete is made and placed and also with the degree of structural safety that is required. The degree of saturation of freshly placed concrete which has no access to an external source of water will be reduced as the concrete hardens and water is used in the hydration process. Under such conditions, the time at which the degree of saturation becomes reduced below the level which would cause damage by freezing has been linked to both "critical age" and "critical strength."

Critical (minimum) strengths, which should be developed before freezing is allowed, have been reported as: 350 to $640 \mathrm{psi}$ in Sweden, ${ }^{8} 1000$ to $1500 \mathrm{psi}$ in Canada, ${ }^{15} 700$ to $1280 \mathrm{psi}$ in the Soviet Union, ${ }^{8} 500$ psi in the United States, ${ }^{1} 850$ psi in Japan, ${ }^{17}$ and 2100 psi in Switzerland. ${ }^{8}$ Critical (minimum) ages have varied from 8 to 48 hours. It has been suggested that the critical age concept is more valid than critical strength. ${ }^{19}$ The absolute strength of concrete at the moment of freezing was found in this study to be not as important as the extent of cement hydration that has occurred and the amount of freezable water remaining in the concrete. Strength determinations are simpler to make, however, and the critical strength concept is widely used. Most well-proportioned concretes reach 500 psi during the second day when cured at $50^{\circ} \mathrm{F}$. Non-air-entrained concrete made with type I cement at a water/cement ratio of 0.57 has been shown to withstand one cycle of freezing after about 18 hours of aging. ${ }^{15}$

The recommended times for protection from freezing vary somewhat. The American Concrete Institute's "Recommended Practice for Cold Weather Concreting (ACI-306-66)" states that in the fall, from the time of the first frost until the mean daily temperature falls below $40^{\circ} \mathrm{F}$ for more than 
Table I. Times of protection recommended at minimum specified temperatures.

\begin{tabular}{lcccc} 
For durability only \\
Type III, \\
Service category & $\begin{array}{c}\text { Type I } \\
\text { or II } \\
\text { cement }\end{array}$ & $\begin{array}{c}\text { Tecelerator or } \\
\text { extra sack cement }\end{array}$ & $\begin{array}{c}\text { Type I } \\
\text { or II } \\
\text { cement }\end{array}$ & $\begin{array}{c}\text { Type III, } \\
\text { accelerator or } \\
\text { extra sack cement }\end{array}$ \\
\hline No load, no exposure & 2 & & & 1 \\
No load, exposed & 3 & 1 & 2 & 2 \\
Partial load, exposed & 3 & 2 & 3 & 4 \\
Full load, exposed & 3 & 2 & 6 & (See reference 1 and App.) \\
\hline
\end{tabular}

one day in a row, all concrete should be protected from freezing for at least the first 24 hours after it is placed. During colder weather, when mean daily temperatures are generally below $40^{\circ} \mathrm{F}$, concrete should be placed at temperatures not lower than the following:

\section{Type of structure}

Very thin sections

Thin sections

Moderately massive sections

Massive sections

\section{Minimum temperature, ${ }^{\circ} \mathrm{F}$}

55

50

45

40

These concrete temperatures should be maintained for the time periods given in Table $\mathrm{I}$.

The RILEM (Réunion Internationale des Laboratoires d'Essais et de Recherches sur les Matériaux et les Constructions) Recommendations for Winter Concreting, ${ }^{16}$ which is often used as the basis for European specifications, states that the necessary prehardening times for standard cements are:

Necessary time, days

$1 / 2$ to 2

$3 / 4$ to 3

1 to 4

\section{Concrete temperature, ${ }^{\circ} \mathrm{F}$}

68

54

41

The minimum time periods recommended by RILEM refer to a water/cement ratio of 0.4 , and the higher figures represent a water/cement ratio of 0.8 . A review ${ }^{11}$ of cold weather recommended practices for Belgium, Denmark, Germany, Sweden, and the United Kingdom found that the RILEM recommendations were more cautious than the recommended or prescribed practices in most of these countries. Although the practices varied from country to country, all were in accord that special precautions must be introduced when ambient temperatures fall to $40^{\circ} \mathrm{F}$ or below.

The cold weather concreting requirements of the Canadian Standards Association are contained in CSA Standard A 23.1, 1973. ${ }^{3}$ CSA Standard A 23.1 states that when the air temperature is at or below $40^{\circ} \mathrm{F}$, or when there is a probability of it falling to that limit within 24 hours of placing, the temperature of the concrete in place shall be within the following limits for the indicated classes of concrete: 


\author{
Least dimension \\ of section
}

Less than 12 in.

12 to 36 in.

37 to 72 in.

Greater than 72 in.

\section{Minimum temperature of \\ concrete as placed, ${ }^{\circ} \mathrm{F}$}

These temperatures correspond to those of ACI 306-66 but the thickness of concrete is better defined in the CSA Standard. The CSA Standard specifies that effective means shall be provided for maintaining the temperature of the concrete in place above the minimum limits (shown above) until sufficient hydration occurs to protect the concrete from frost damage. The degree of hydration will have been attained when the concrete reaches a compressive strength of 1000-1500 psi.

The principal guidance for cold weather concreting provided by the Corps of Engineers is contained in five documents. ${ }^{4-7} 9$ Three are guide specification $s^{5-7}$ and give specific limits. These limits are summarized in Table II. The recommendations for arctic concrete when temperatures are less than $40^{\circ} \mathrm{F}$ are contained in TM5-349, Arctic Construction, ${ }^{9}$ and are summarized in Table III.

Table III points out that in cold weather concreting situations, the concrete materials must be of such temperatures that, when properly proportioned, the resulting concrete will have a temperature sufficiently high for the hydration of the cement to begin. Once it starts, it must be sustained for periods long enough for the concrete to develop sufficient strength (or degree of hydration) so that freezing will not damage the concrete. The usual methods to accomplish this can be summarized as follows: ${ }^{8} 20$

A. Treatment of the materials

1. Heating of the materials

2. Heating (usually electrical) of the freshly placed concrete

3. Use of cement with high heat development

4. Use of chemical admixtures which either accelerate the reaction of the cement or depress the freezing point of the water in the concrete.

B. Methods to prevent heat losses

1. Insulating covering

2. Heating

Considering the economics of winter concreting, the least expensive method would be one that required the least manpower, time, and equipment. Of the above methods, A3 and A4 would come the closest to satisfying these criteria. But, as can be seen from the requirements for arctic concrete in Table III, even the use of type IIl high early strength cement, rapid hardening alumina cement, or an accelerating admixture with calcium chloride $\left(\mathrm{CaCl}_{2}\right)$ does not eliminate the requirement for protection after placement, although the times of required protection are greatly reduced. Ideally, a cement which gains strength very rapidly, as well as producing quantities of heat sufficient to protect the concrete from freezing, would reduce the cost of winter concreting and possibly extend the winter concreting season for a few more months. The experimental work contained in this report is an examination of a cement, called regulated-set cement, which appears to have great promise in satisfying these criteria. 
Table II. Summary of U.S. Army Corps of Engineers guide specifications

for nonarctic concrete construction.

\begin{tabular}{|c|c|c|c|}
\hline $\begin{array}{c}\text { Type of } \\
\text { specification }\end{array}$ & $\begin{array}{l}\text { Minimum } \\
\text { temperature } \\
\text { of concrete } \\
\text { as placed. }{ }^{\circ} \mathrm{F}\end{array}$ & $\begin{array}{l}\text { Minimum } \\
\text { teimperature } \\
\text { recommended } \\
\text { for protection, }{ }^{\circ} \mathrm{F}\end{array}$ & $\begin{array}{l}\text { Time of } \\
\text { protection } \\
\text { recommended }\end{array}$ \\
\hline $\begin{array}{l}\text { CE } 806.01 \text {, concrete } \\
\text { pavement for roads } \\
\text { and airfields (mili- } \\
\operatorname{tary})^{5}\end{array}$ & $50-85$ & 50 & $\begin{array}{l}3 \text { days, then above freezing for remainder of } \\
\text { specified curing period }\end{array}$ \\
\hline $\begin{array}{l}\text { CE } 204 \text {, concrete } \\
\text { for building con- } \\
\text { struction (mili- } \\
\text { tary) }\end{array}$ & 50 & 50 & $\begin{array}{l}3 \text { days when made with types III and IIIA } \\
\text { cement; } 7 \text { days when made with types I, IA } \\
\text { II and IIA cement; } 10 \text { days when made with } \\
\text { types IS, IS-A, S, SA or N cements or with } \\
\text { blends containing pozzolana, natural cement } \\
\text { or slag cement }\end{array}$ \\
\hline \multirow[t]{2}{*}{$\begin{array}{l}\text { CE } 1401.01 \text {, concrete } \\
\text { for civil works con- } \\
\text { struction? }\end{array}$} & 40 & $\begin{array}{l}\quad 50 \\
\text { (minimum dimen- } \\
\text { sion of section } \\
<12 \text { in.) }\end{array}$ & Same as for CE 806.01 \\
\hline & 40 & $\begin{array}{l}40 \\
\text { (minimum dimen- } \\
\text { sion of section } \\
>12 \text { in.) }\end{array}$ & Same as for CE 806.01 \\
\hline
\end{tabular}

Table III. Guide specifications for concrete construction given in Department of the Army TM5-349, Arctic Construction.

\begin{tabular}{|c|c|c|c|c|}
\hline $\begin{array}{l}\text { Type of } \\
\text { construction }\end{array}$ & $\begin{array}{l}\text { Ambient } \\
\text { temperature, } \\
\mathrm{F}_{\mathrm{F}}\end{array}$ & $\begin{array}{l}\text { Minimum } \\
\text { temperature } \\
\text { of concrete } \\
\text { as placed, }{ }^{\circ} \mathrm{F}\end{array}$ & $\begin{array}{l}\text { Minimum } \\
\text { temperature } \\
\text { recommended } \\
\text { for protection, }{ }^{\circ} \mathrm{F}\end{array}$ & $\begin{array}{l}\text { Time of } \\
\text { protection } \\
\text { recommended }\end{array}$ \\
\hline \multirow[t]{6}{*}{ Temporary } & 15 & 60 & 70 & $\begin{array}{c}12 \mathrm{hr} \\
\text { (no } \mathrm{CaCl}_{2} \text { added) }\end{array}$ \\
\hline & & & & $\left(2 \% \mathrm{CaCl}_{2}\right.$ added $)$ \\
\hline & & & . & $\begin{array}{c}4 \mathrm{hr} \\
\left(4 \% \mathrm{CaCl}_{2} \text { added }\right)\end{array}$ \\
\hline & 20 & 70 & 70 & $\begin{array}{c}2 \mathrm{hr} \\
\left(4 \% \mathrm{CaCl}_{2} \text { added }\right)\end{array}$ \\
\hline & . 32 & 70 & \multirow{2}{*}{\multicolumn{2}{|c|}{$\begin{array}{l}\text { No protection if made with type III cement and } \\
2 \% \mathrm{CaCl}_{2}\end{array}$}} \\
\hline & 40 & 40 & & \\
\hline \multirow{3}{*}{$\begin{array}{l}\text { Permanent } \\
\text { with normal } \\
\text { cement }\end{array}$} & & & & \\
\hline & $<40$ & 70.80 & 70 & 3 days \\
\hline & & & 50 & 5 days \\
\hline \multirow{2}{*}{$\begin{array}{l}\text { with type III } \\
\text { cement }\end{array}$} & & & 70 & 2 days \\
\hline & & & 50 & 3 days \\
\hline $\begin{array}{l}\text { with high- } \\
\text { alumina cement }\end{array}$ & & $50-70$ & 50 & 1 day \\
\hline Massive & $<40$ & $70-80$ & \multicolumn{2}{|c|}{$\begin{array}{l}\text { No protection required unless ambient tempera- } \\
\text { tures }<15^{\circ} \mathrm{F}\end{array}$} \\
\hline
\end{tabular}


Table IV. Total heat of hydration of cement type at $70^{\circ} \mathrm{F} .^{13}$

\begin{tabular}{|c|c|c|c|c|c|c|}
\hline \multirow[b]{3}{*}{ Cement type } & \multicolumn{6}{|c|}{$\begin{array}{l}\text { Total cumulative heat of hydration at } \\
\qquad 70^{\circ} \mathrm{F}(\mathrm{cal} / \mathrm{g})\end{array}$} \\
\hline & \multicolumn{6}{|c|}{ Age. days } \\
\hline & 1 & 3 & 7 & 28 & 90 & 365 \\
\hline & & & & 1 & & \\
\hline I, Normal & - & 61 & 80 & 96 & 104 & 109 \\
\hline III, Rapid hardening & - & 75 & 92 & 101 & 107 & 113 \\
\hline IV, Low heat & -- & 41 & 50 & 66 & 75 & 81 \\
\hline ASTM type II & -. & 47 & 61 & 80 & $\mathbf{8 8}$ & 95 \\
\hline High-alumina ${ }^{18}$ & 85 & 86 & 87 & -- & 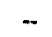 & 110 \\
\hline Regulated-set* & 78 & 109 & 115 & 118 & - & -. \\
\hline
\end{tabular}

- WES data.

Regulated-set cement, often called simply "reg-set," is a recent development of the Portland Cement Association. It is not a mixture of cements or an admixture, but it is a portland cement with some new ingredients blended in the kiln. The principal difference between reg-set and ordinary portland cement is that regulated-set cement contains a new ingredient, calcium fluoroaluminate, which provides very high early strength. Associated with the development of this high early strength is the liberation of large quantities of heat. This heat, a by-product of the reaction of the cement and water, is described by an index called the heat of hydration. The heat of hydration is expressed as the total heat liberated per gram of cement up to any specified age. A comparison of some average data for the heats of hydration of different types of cements at $70^{\circ} \mathrm{F}$ is summarized in Table IV. For most portland cements the temperature at which hydration takes place affects the rate of heat development as shown in the following tabulation: ${ }^{14}$

\begin{tabular}{lcccc} 
& \multicolumn{4}{c}{$\begin{array}{c}\text { 3-day heat of hydration (cal/g) } \\
\text { developed at }\end{array}$} \\
\cline { 2 - 6 } Cement type & $40^{\circ} \mathrm{F}$ & $75^{\circ} \mathrm{F}$ & $90^{\circ} \mathrm{F}$ & $105^{\circ} \mathrm{F}$ \\
\hline & & & & \\
I, Normal & 37 & 68 & 74 & 80 \\
III, Rapid hardening & 58 & 83 & 85 & 93 \\
IV, Low heat & 26 & 47 & 46 & 51
\end{tabular}

With high-alumina cements the curing temperature has little effect on the total heat involved, but the rate at which the heat is liberated in the early stages of hydration is not increased with a rise in curing temperature, as is the case with portland cement. ${ }^{18}$ The effects of curing temperature on the rate of hydration of reg-set cement are not known to the authors. Other factors such as cement fineness and water content also influence the amount and rate at which heat is liberated. As can be seen above, a greater amount of heat is liberated at early ages by reg-set cements than by other cements.

Initial and final set occur very soon after mixing for reg-set mixtures, thus limiting their handling time ("handling time" is defined as the maximum time before the concrete must be placed in its final position). At $70^{\circ} \mathrm{F}$, regulated-set concrete has a controlled handling time which can be varied between 2 and 45 minutes. This variation can be regulated when the cement is manufactured by blending different proportions of the early strength component (calcium fluoroaluminate) and also by the use of retarding additivies (such as citric acid) or by changing the temperature of the mixture. Further, handling time is increased with an increase in the water/cement ratio, lower cement content, and continued mixing. 
At $70^{\circ} \mathrm{F}$ and without additives, regulated-set concrete will develop a compressive strength of $1000 \mathrm{psi}$ or more as early as $1 \frac{1}{2}$ hours after mixing. This early strength is directly proportional to the percentage of calcium fluoroaluminate in the cement. An increased percentage of this high early strength component causes a higher early strength and a shorter handling time. The various cement companies which have manufactured reg-set cement have not, however, formulated their cement to any national standard but to their own specifications. Thus, the behavior and properties of reg-set cement vary according to its source.

Reg-set cement exhibits a rapid gain in strength within one or two hours to a level which is dependent on the percentage of the high early strength component in the cement. The strength development of the calcium fluoroaluminate is then nearly complete, and little or no strength gain occurs until the normal silicate hydration becomes effective after about one day. The long-term strength, the rate of gain of strength after one day, and other physical properties are then comparable to those of completely cured concrete made with type I and type III cements.

The relationship of strength and durability to water/cement ratio and the response to additives are similar in both reg-set and portland cement; however, reg-set cement is considerably more sensitive to variations in these parameters. Regulated-set cement is particularly sensitive to the temperature of the mixture and to certain retarders such as citric acid. The sulfate resistance of reg-set cement is reported to be about the same as type I cement.

Little published information is available on the use and behavior of regulated-set cement concrete. The work described in this report explores the possibility of using regulated-set centent in cold weather concreting operations.

\section{PHASE I: MORTAR PHASE}

The work conducted in the mortar phase (Phase I) consisted essentially of tests using mortar mixtures as a basis for judging the effectiveness of different variables. Forty-one mortar mixtures were made and evaluated for workability (by visual inspection) and for compressive strength. The results are shown in Table $V$. The compressive strength of the mortar mixtures was used as an indicator to determine which mixtures and methods would be most-suitable for use in the concrete mixture phase (Phase II) of the program. Mixtures were proportioned to contain varying water/ cement ratios and a constant sand/cement ratio of 2.75 (by weight), except for mixtures CW-1 and CW-2, which had a sand/cement ratio of 3.50 .

Both type III and reg-set cement were tested in the mortar phase. The regulated-set portland cement had a time of set of approximately 10 minutes when the mortar temperature was $73^{\circ} \mathrm{F}$, while the time of set of the type III cement at $73^{\circ} \mathrm{F}$ was 3 to $31 / 2$ hours.

Test specimens (2-in. cubes) were made from each of the 41 mortar mixtures when cured, and the strength of each mixture at a given age was ascertained by compression testing. Two cubes were made for testing at each age.

The mortar tests were conducted to discover the most promising mixtures which could then be further developed in the concrete phase of the program. This approach not only identified the most suitable mixtures, but also gave insight into the precautions which should be heeded when placing concrete or mortar mixtures at low temperatures. Suitable changes were made in the mortar mixtures and one of them was selected for use in the concrete phase of the program. The test program of Phase I is summarized in Table VI. 
Table V. Mortar mixtures containing quick set cements.

Water.

Cement WRA $+A E A *$ Retarder cement Temperarures, ${ }^{\circ} F$, pirior to mixing Similar $C W$ - used $\left(\mathrm{cm}^{3}\right)\left(\mathrm{cm}^{3}\right)$ $\boldsymbol{g}$ ntio Cement Sand Water

Compressive strength, psi

\begin{tabular}{|c|c|c|c|c|c|c|c|c|c|c|c|c|c|c|c|c|c|c|c|}
\hline$C W-$ & used & $\left(\mathrm{cm}^{3}\right)$ & $\left(\mathrm{cm}^{3}\right)$ & $g$ & ratio & Cement & Sand & Water & Curing & Mixing & mixture & $1 / 4$ & $I$ & 3 & 5 & 7 & 28 & of mixing & Remarks \\
\hline $1 *$ & Reg-set & - & - & - & 0.6 & 15 & 15 & 69 & 15 & 15 & - & 410 & - & - & -- & 600 & - & W-C-S & Specimen frozen when tested \\
\hline $2 *$ & Reg-set & - & - & - & 0.6 & 10 & 10 & 71 & 15 & 15 & - & 10 & - & - & - & 20 & 60 & W.C-S & $\begin{array}{l}\text { Thawed } 45 \mathrm{~min} \text {. before } \\
\text { testing. }\end{array}$ \\
\hline $3^{*}$ & Reg-set & - & - & - & 0.5 & 15 & 15 & 73 & 15 & 73 & - & 10 & - & - & - & 155 & 360 & W-C-S & \\
\hline 4 & Reg-set & - & - & - & 0.6 & 15 & 15 & 100 & 15 & 73 & - & 10 & - & - & - & 120 & 330 & w-C-S & \\
\hline 5 & Reg-set & - & - & - & 0.6 & 73 & 15 & 150 & 15 & 73 & 10 & 15 & - & - & - & 85 & 260 & W.C-S & Mix very dry \\
\hline 6 & Reg-set & - & - & - & 0.6 & 73 & 42.5 & 100 & 15 & 73 & - & 30 & -. & - & - & 1085 & 1525 & W-C-S & Mix moderately dry \\
\hline 7 & Reg-set & - & - & - & 0.5 & 40 & 40 & 40 & 40 & 40 & - & 30 & -- & 3740 & - & 5000 & - & W-C.S & \\
\hline 8 & Reg-set & - & - & - & 0.6 & 40 & 40 & 40 & 40 & 40 & - & 10 & - & 2225 & - & 3300 & - & W.C.S & Cubes soft at $6 \mathrm{hr}$ \\
\hline 9 & Reg-set & - & - & - & 0.5 & 73 & 40 & 150 & 15 & 73 & - & - & - & 85 & - & 195 & - & W-C-S & Mix dry (flash set) \\
\hline 10 & Reg-set & - & - & - & 0.6 & 73 & 40 & 150 & 15 & 73 & $\mathbf{5}$ & - & -- & 65 & - & 135 & - & W-C-S & Mix dry (flash set) \\
\hline 11 & Type III & - & - & - & 0.5 & 40 & 40 & 40 & 40 & 40 & - & - & -- & - & 3370 & 3670 & 6540 & W-C-S & \\
\hline 12 & Type III & - & - & - & 0.6 & 40 & 40 & 40 & 40 & 40 & - & - & - & - & 2870 & 3155 & 5325 & w-c-s & Wet mix \\
\hline 13 & Reg-set & - & - & - & 0.4 & 73 & 40 & 100 & 15 & 73 & - & - & - & 2035 & - & 2550 & 3590 & W-C-S & Mix very dry \\
\hline 14 & Reg-set & - & - & - & 0.4 & 73 & 40 & 100 & 15 & 73 & - & - & 1940 & 2680 & - & 3940 & - & W-WRA-C-S & $\begin{array}{l}\text { Good consistency } \\
\text { (flash set) }\end{array}$ \\
\hline 15 & Reg-set & 7 & - & - & 0.4 & 73 & 15 & 100 & 15 & 73 & $20,25,26$ & - & 1875 & 2320 & - & 3405 & - & W-WRA-C-S & Medium dry (flash set) \\
\hline 16 & Reg-set & 10.5 & - & - & 0.4 & 73 & 40 & 100 & 15 & 73 & - & - & 740 & 1235 & - & 1605 & - & S-W-WRA-C & Good consistency \\
\hline 17 & Reg-set & 10.5 & - & - & 0.4 & 73 & 15 & 100 & 15 & 73 & - & - & 20 & 25 & - & 110 & - & S-W-WRA-C & Good consistency \\
\hline 18 & Reg-set & 7 & - & - & 0.45 & 73 & 15 & 100 & 15 & 73 & 25 & - & 40 & 90 & - & 285 & - & S-W-WRA-C & Good consistency \\
\hline 19 & Reg-set & 7 & - & - & 0.45 & 73 & 15 & 150 & 15 & 73 & - & - & 1460 & 2370 & - & 3010 & - & S-W-WRA-C & $\begin{array}{l}\text { Good consistency } \\
\text { (flash set) }\end{array}$ \\
\hline 20 & Reg-set & 7 & - & - & 0.4 & 73 & 15 & 100 & 15 & 73 & 21 & - & 670 & 1750 & - & 2120 & - & S-W-WRA-C & \\
\hline 21 & Type III & 7 & - & - & 0.4 & 73 & 15 & 150 & 15 & 73 & 20 & - & 25 & 65 & - & 105 & - & S-W-WRA-C & $\begin{array}{l}\text { Good consistency, did not } \\
\text { set at } 15^{\circ} \mathrm{F}\end{array}$ \\
\hline 22 & Reg-set & 7 & - & $\begin{array}{l}\text { Citric acid } \\
\quad 0.6 \mathrm{~g}\end{array}$ & 0.45 & 73 & 15 & 100 & 15 & 73 & - & - & 10 & 15 & - & 20 & - & S-W-WRA-C & $\begin{array}{l}\text { Good consistency, did not } \\
\text { set at } 15^{\circ} \mathrm{F}\end{array}$ \\
\hline 23 & Reg-set & 7 & - & $\begin{array}{l}\text { Plastiment } \\
\quad 3.6 \mathrm{~g}\end{array}$ & 0.45 & 73 & 15 & 120 & 15 & 73 & - & - & 50 & 75 & - & 370 & - & S-W-P-C & $\begin{array}{l}\text { Moderately dry, did not set } \\
\text { at } 15^{\circ} \mathrm{F}\end{array}$ \\
\hline 24 & Reg-set & 7 & - & - & 0.45 & 73 & 15 & 120 & 15 & 73 & - & - & 20 & 220 & - & 640 & -- & S-W-WRA-C & $\begin{array}{l}\text { Good consistency, did not } \\
\text { set }\end{array}$ \\
\hline 25 & Reg-set & 7 & - & - & 0.4 & 73 & 15 & 100 & 15 & 73 & 18,28 & - & 75 & 520 & 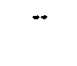 & 1790 & - & S-W-WRA-C & $\begin{array}{l}\text { Good consistency, did not } \\
\text { set }\end{array}$ \\
\hline 26 & Reg-set & 3.5 & - & - & 0.4 & 73 & 15 & 100 & 15 & 73 & 31 & - & 140 & 1060 & - & 2735 & - & S-W-WRA-C & $\begin{array}{l}\text { Good consistency, slight } \\
\text { flash set }\end{array}$ \\
\hline 27 & Reg-set & 3.5 & - & - & 0.45 & 73 & 15 & 100 & 15 & 73 & 31 & - & 240 & 730 & $\cdot \cdot$ & 2060 & - & S-W-WRA-C & Good consistency \\
\hline 28 & Reg-set & 7 & - & - & 0.4 & 73 & 15 & 100 & 15 & 73 & 25 & - & 945 & 1700 & - & 2495 & - & S-W-WRA-C & $\begin{array}{l}\text { Medium dry, slight fuil } \\
\text { flash set }\end{array}$ \\
\hline
\end{tabular}




\begin{tabular}{|c|c|c|c|c|c|c|c|c|c|c|c|c|c|c|c|c|c|c|c|}
\hline \multirow[b]{2}{*}{ CW. } & \multirow[b]{2}{*}{$\begin{array}{c}\text { Cement } \\
\text { used }\end{array}$} & \multirow[b]{2}{*}{$\begin{array}{l}\text { WRA } \dagger \\
\left(\mathrm{cm}^{3}\right)\end{array}$} & \multirow[b]{2}{*}{$\begin{array}{l}A E A^{* *} \\
\left(\mathrm{~cm}^{3}\right)\end{array}$} & \multirow[b]{2}{*}{$\begin{array}{c}\text { Retarder } \\
g\end{array}$} & \multirow{2}{*}{$\begin{array}{c}\text { Water- } \\
\text { cement } \\
\text { ratio }\end{array}$} & \multirow{2}{*}{\multicolumn{5}{|c|}{ Temperatures, ${ }^{\circ} \mathrm{F}$, prior to mixing }} & \multirow[b]{2}{*}{$\begin{array}{l}\text { Similar } \\
\text { mixture }\end{array}$} & \multicolumn{6}{|c|}{$\frac{\text { Compressive strength, psi }}{\text { Days }}$} & \multirow[b]{2}{*}{$\begin{array}{l}\text { Sequence } \\
\text { of mixing }\end{array}$} & \multirow[b]{2}{*}{ Remarks } \\
\hline & & & & & & & & & & & & $1 / 4$ & $I$ & $\frac{D a}{3}$ & 5 & 7 & 28 & & \\
\hline 29 & Reg-set & 3.5 & - & - & 0.45 & 73 & 15 & 100 & 15 & 73 & - & - & 1830 & 2335 & - & 3335 & - & W-WRA-C-S & Mix dry \\
\hline 30 & Reg-set & - & 7 & - & 0.45 & 73 & 15 & 100 & 15 & 73 & 18 & - & 880 & 1360 & - & 1775 & - & W.WRA-C-S & AEA in place of WRA \\
\hline 31 & Reg-set & - & 3.5 & - & 0.5 & 73 & 15 & 100 & 15 & 73 & 26,27 & - & 365 & 700 & .. & 1360 & - & W-WRA-C-S & AEA in place of WRA \\
\hline 32 & Reg-set & 7 & - & - & 0.45 & 73 & 15 & 100 & 15 & 73 & - & - & 760 & 1235 & - & 1775 & - & W-WRA-C-S & \\
\hline 33 & Reg-set & 3.5 & - & - & 0.5 & 73 & 15 & 100 & 15 & 73 & - & - & 1270 & 1485 & - & 2705 & - & W-WRA-C-S & \\
\hline 34 & Reg-set & - & - & - & 0.5 & 73 & 15 & 100 & 15 & 73 & - & - & 45 & 695 & - & 1605 & - & W-WRA-C-S & Mix dry \\
\hline 35 & Reg-set & 10.5 & - & - & 0.4 & 73 & 15 & 100 & 15 & 73 & 17 & - & 9 & 45 & .- & 420 & - & W-WRA-C-S & Excessive entrained air \\
\hline 36 & Reg-set & 7 & - & - & 0.45 & 40 & 15 & 100 & 15 & 40 & - & - & $\mathbf{5}$ & 10 & - & 25 & - & W-WRA-C-S & Did not set \\
\hline 37 & Reg-set & 3.5 & - & - & 0.5 & 40 & 15 & 100 & 15 & 40 & - & - & 10 & 85 & - & 155 & - & W-WRA-C-S & Did not set \\
\hline 38 & Reg-set & 3.5 & - & - & 0.5 & 40 & 15 & 140 & 15 & 40 & 39 & - & 1265 & 1855 & -. & 2455 & - & W-WRA-C-S & Harsh mix \\
\hline 39 & Reg-set & 3.5 & - & - & 0.5 & 40 & 15 & 140 & 15 & 40 & 28 & - & 640 & 1315 & - & 2350 & - & W-WRA-S-C & Good mix \\
\hline 40 & Reg-set & 3,5 & - & - & 0.5 & 40 & 15 & 140 & 15 & 40 & - & - & $\begin{array}{l}\text { Mix di } \\
\text { moids }\end{array}$ & id not & $t, s a$ & me as 1 & o. 39 , & except storag & e specimen cast in metal \\
\hline 41 & Reg-et & 3.5 & - & - & 0.45 & 40 & 15 & 140 & 15 & 40 & - & - & 10 & 370 & - & 1100 & - & W-WRA-S-C & Excessive entrained air \\
\hline
\end{tabular}

- Mixture proportions: graded Ottawa sand $2100 \mathrm{~g}$; reg-set cement, $600 \mathrm{~g}$.

† Water reducing admixture.

* Air-entraining admixture. 
Table VI. Summary of test program.

Variables investigated in Phase I were:

A. Water/cement ratio. Four water/cement ratios were used.

\begin{tabular}{cc} 
Water/cement ratio & Number of mixtures made \\
\cline { 2 - 2 } 0.6 & 8 \\
0.5 & 10 \\
0.45 & 12 \\
0.4 & 11
\end{tabular}

B. Type of cement and sand. All mixtures contained either type III portland cement or regulated-set portland cement.

\begin{tabular}{lc}
\multicolumn{1}{c}{ Cement } & Number of mixtures made \\
Type III & 3 \\
Regulated set & 38
\end{tabular}

The sand used was 20-30 graded Ottawa sand.

C. Admixtures. Two retarders, one air-entraining admixture, and one water-reducing admixture were used in these tests as follows:

Admixture
"Plastiment" (water-reducing retarder)
Citric acid (retarder)
"Air-In" (air-entraining admixture)
"WRA" (water-reducing admixture)
None

\section{Number of mix tures made}

1
1
2
24
13

D. Sequence of adding materials to mixer. Two sequences were used. The order of addition of materials to mixer was either water, admixture, cement and sand (26 mixtures) or water, admixture, sand and cement (15 mixtures).

E. Mixing temperatures. The mortar mixtures were mixed at $15^{\circ} \mathrm{F}$ ( 2 mixtures), $40^{\circ} \mathrm{F}$ (10 mixtures), or $73^{\circ} \mathrm{F}$ (29 mixtures).

F. Type of molds and specimens. Two types of molds were used. Two mixtures were placed in uninsulated metal molds, and the remaining 39 mixtures were placed in insulated (wooden) molds. All specimens were 2 -in. cubes.

G. Temperature of materials. The temperature of the materials used (i.e. water, cement, or sand) was as follows:

1) Water: $40^{\circ}, 73^{\circ}, 100^{\circ}, 120^{\circ}, 140^{\circ}$ or $150^{\circ} \mathrm{F}$.

2) Cement: $15^{\circ}, 40^{\circ}$ or $73^{\circ} \mathrm{F}$.

3) Sand (graded Ottawa): $15^{\circ}$ or $40^{\circ} \mathrm{F}$.

4) Admixture: $73^{\circ} \mathrm{F}$.

H. Curing temperature. All mixtures were cured at either $15^{\circ}$ or $40^{\circ} \mathrm{F}$. Thirty-seven mixtures were cured at $15^{\circ} \mathrm{F}$, and four mixtures were cured at $40^{\circ} \mathrm{F}$. Molds were equilibrated overnight at the proposed curing temperature for any given mixture prior to use.

1. Length of curing. All test specimens remalned in the molds until time of compression test. Curing ages varied from 6 hours to 28 days. All frozen specimens were thawed at $73^{\circ} \mathrm{F}$ for A5 minutes prior to testing.

On the basis of the mortar mixtures cast in the mortar phase, mixture CW-39 (see Table V) was selected as the most promising for use in the concrete phase. Mixture CW-39 had sufficient air content to be workable and had no tendency to flash set during molding, as had occurred in so many of the other reg-set mixtures. There was also considerable strength development. 
Table VII. Temperature, mixing proportions, and batching sequence.

\begin{tabular}{|c|c|c|c|}
\hline $\begin{array}{l}\text { Temperature } \\
\text { of ingredient } \\
\left({ }^{\circ} \mathrm{F}\right) \\
\end{array}$ & \multicolumn{2}{|c|}{$\begin{array}{l}\text { Mix ture proportions } \\
\text { (for batch of six 2- } \times 2 \text {-in. cubes) }\end{array}$} & $\begin{array}{l}\text { Sequence of } \\
\text { adding to mixer }\end{array}$ \\
\hline 140 & Water & $250 \mathrm{~g}$ & 1 \\
\hline 73 & WRA & $\begin{array}{l}3.5 c^{2} \text { (10.64 fluid oz } \\
\text { per cwt of cement) }\end{array}$ & 2 \\
\hline 15 & Sand & $1375 \mathrm{~g}$ & 3 \\
\hline 40 & Cemen & $500 \mathrm{~g}$ & 4 \\
\hline 15 & \multirow{2}{*}{\multicolumn{2}{|c|}{$\begin{array}{l}\text { Insulated wood molds (made of } \\
3 / 4 \text {-in. marine plyboard) } \\
\text { Paddle mixer }\end{array}$}} & - \\
\hline 40 & & & - \\
\hline
\end{tabular}

The contents of mixture $\mathrm{CW} \cdot 39$ are shown as follows:

\section{Mixture CW.39}

Cement: Regulated-set portland cement

Sand: Graded Ottawa sand

Admixture: "WRA" water-reducing admixture

Water: Demineralized water

Sand/cement ratio: 2.75 (by weight)

Water/cement ratio: 0.50 (by weight)

The temperature of ingredients at batching, the mixture proportions, and batching sequence of mix. ture CW-39 are summarized in Table VII.

Six cubes of mixture CW-39 were cast into molds at $15^{\circ} \mathrm{F}$ for one day. Two of the cubes were then tested for compressive strength after being allowed to stand and thaw at $73^{\circ} \mathrm{F}$ for 45 minutes before testing. The remaining four cubes were moist cured at $73^{\circ} \mathrm{F}$ for two to seven days. The results were:

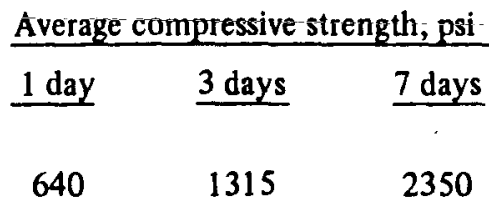

The results of the mortar phase are summarized in Table VIII.

Table VIII. Results of Phase I (mortar phase).

A. Water/cement ratio. As the water/cement ratios increased the compressive strength decreased. This is to be expected in normal mortars but is perhaps more pronounced when the mortars are exposed to freezing temperatures during curing, as ther 0 is more water available for freezing.

B. Type of cement. Regulated-set cement gained more strength when exposed to a $15^{\circ} \mathrm{F}$ temperature during curing than did type III high early strength portland cement. This is due principally to the rapid set and strength development of the res-set cement plus the extra heat liberated which sustains the strength developinent longer.

c. Admixtures.

1. Time of set retander. Citric acid appeared to be more effective in retarding the setting time of reg-set cement than plastiment. 
Table VIII (Cont'd). Results of Phase I (mortar phase).

2. Air-entraining admixture. This appears to be of some benefit in producing strength gain in reg-set cement mortars cured at $15^{\circ} \mathrm{F}$. This is to be expected as air entrainment is known to reduce freezing damage in concrete.

3. Water-reducing admixture. This appears to be slightly more effective than an air-entraining admixture in producing strength gain, as this material reduces the water requirement which benefits strength development as well as reduces the amount of freezable water in the concrete.

D. Sequence of adding materials to mixer. Regulated-set cement should be added in the mixer as the last ingredient. This allows a little more working time before stiffening begins.

E. Mixing and curing temperatures. Lower temperatures produced lower compressive strengths. If mixing water and/or cement and sand were at elevated temperatures prior to mixing and exposure at $15^{\circ} \mathrm{F}$, hydration would begin sooner and sustain itself longer by internal heat production with resulting higher strengths.

F. Type of molds. The more insulation a mold provides, the less heat escapes into the cooler air and the longer the hydration reaction is sustained.

\section{PHASE II: CONCRETE PHASE}

\section{Effect of time of freezing}

Mixture No. CW.39, developed in the mortar phase, was selected as the mixture for use as a guide in designing a basic concrete mixture for the concrete phase. The designed concrete mixture contained regulated-set cement, $3 / 4$-in. maximum-size limestone coarse aggregate, and limestone sand. Saturated-surface dry batch weights were as follows:

Material .

Cement

Fine aggrega te

Coarse aggregate

Water
Saturated-surface dry

batch weights, lb

The mixture contained an actual cement factor of $500 \mathrm{lb} / \mathrm{yd}^{3}$, a water/cement ratio of 0.53 , and an entrained air content of $8.5 \%$, and it produced a slump of $2 \frac{112}{2}$ in. All materials and molds were stored at $35^{\circ} \mathrm{F}$ until immediately prior to mixing. Mixing and molding were done at $73^{\circ} \pm 2^{\circ} \mathrm{F}$. The cement was introduced into the mixer as the last step in the charging process, and the concrete mixed for $1 / 2$ minutes.

Ten 6- $\times$ 6- $\times$ 36-in.-long concrete beams were cast from the above mixture. The beams were later sawed into five $6-\times 6-\times 6$-in. cubes. The beams were exposed to temperatures as follows:

1. Two beams ( 10 cubes) were exposed at $70^{\circ} \pm 3^{\circ} \mathrm{F}$ and 90 to $100 \%$ relative humidity immediately after casting.

2. Two beams ( 10 cubes) were exposed at $15^{\circ} \mathrm{F}$ immediately after casting. The beams were covered with damp burlap until placed at $15^{\circ} \mathrm{F}$.

3. Two beams ( 10 cubes) were exposed at $15^{\circ} \mathrm{F} 1$ hour after casting. The beams were covered as in 2 above until placed at $15^{\circ} \mathrm{F}$. 

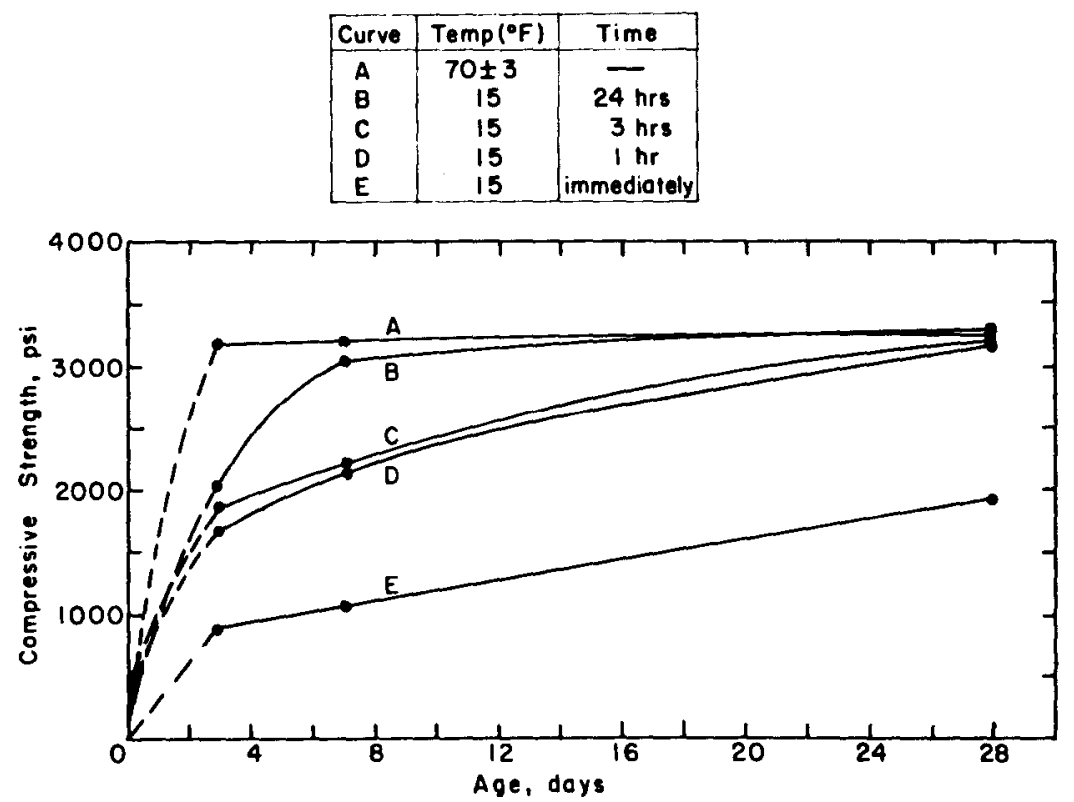

Figure 1. Effect of age of specimens when exposed to freezing temperature upon compressive strength.

4. Two beams ( 10 cubes) were exposed at $15^{\circ} \mathrm{F} 3$ hours after casting. The beams were covered with damp burlap until placed at $15^{\circ} \mathrm{F}$.

5. Two beams ( 10 cubes) were exposed at $15^{\circ} \mathrm{F} 24$ hours after casting. The beams were placed at room temperature $\left(70^{\circ} \pm 3^{\circ} \mathrm{F}\right)$ and $90-100 \%$ relative humidity until exposed at $15^{\circ} \mathrm{F}$.

Two cubes from each of the five exposures were tested in compression at 3,7 and 28 days age. Frozen cubes were thawed for two hours at room temperature prior to breaking.

Compressive strength test results are shown in Table IX. These results, also shown graphically in Figure 1, indicate that concrete containing reg-set cement exhibits the following properties:

1. Concrete ingredients initially stored at 35 to $40^{\circ} \mathrm{F}$, mixed and molded at $73^{\circ} \mathrm{F}$, and placed at $15^{\circ} \mathrm{F}$ immediately after casting had a three-day strength of slightly less than 1000 psi and continued to gain strength while exposed at $15^{\circ} \mathrm{F}$.

2. The longer the mixture remains above freezing before exposure to $15^{\circ} \mathrm{F}$ the greater the subsequent 28-day strength.

3. Specimens exposed at $70^{\circ} \pm 3^{\circ} \mathrm{F}$ until 24 hours old then exposed at $15^{\circ} \mathrm{F}$ exhibited almost as much strength after seven days age as companion specimens exposed at $70^{\circ} \pm 3^{\circ} \mathrm{F}$ for the full time.

4. The 28-day strengths of all specimens kept at $70^{\circ} \pm 3^{\circ} \mathrm{F} 1,3$ and 24 hours before exposure at $15^{\circ} \mathrm{F}$ were almost as great as those of specimens exposed at $70^{\circ} \pm 3^{\circ} \mathrm{F}$ for the full time .

5. Specimens exposed to $70^{\circ} \pm 3^{\circ} \mathrm{F}$ due to slight delays before freezing at $15^{\circ} \mathrm{F}$ gained strength slower than control specimens, but at 28 days age were practically as strong as the specimens exposed at $70^{\circ} \pm 3^{\circ} \mathrm{F}$ for the full time. Specimens exposed to $15^{\circ} \mathrm{F}$ immediately after casting had $60 \%$ of the control specimens' strength at 28 days age. 
Table IX. Effect of time of low temperature exposure upon compressive strength.

\begin{tabular}{|c|c|c|c|c|}
\hline Storage & Specimen & Comp & ssive str & th, psi \\
\hline condition & & 3 days & 7 days & 28 days \\
\hline $\begin{array}{l}15^{\circ} \mathrm{F} \text { immediately } \\
\text { after casting }\end{array}$ & $\begin{array}{l}1 \\
2\end{array}$ & $\begin{array}{l}890 \\
920\end{array}$ & $\begin{array}{r}980 \\
1120\end{array}$ & $\begin{array}{l}2070 \\
1780\end{array}$ \\
\hline & Average & 910 & 1050 & 1930 \\
\hline $\begin{array}{l}15^{\circ} \mathrm{F} \text { I hr after } \\
\text { casting }\end{array}$ & $\begin{array}{l}1 \\
2\end{array}$ & $\begin{array}{l}1770 \\
1560 \\
\end{array}$ & $\begin{array}{l}2130 \\
2120 \\
\end{array}$ & $\begin{array}{l}3150 \\
3210 \\
\end{array}$ \\
\hline & Average & 1670 & 2120 & 3180 \\
\hline $\begin{array}{l}15^{\circ} \mathrm{F} 3 \mathrm{hr} \text { after } \\
\text { casting }\end{array}$ & $\begin{array}{l}1 \\
2\end{array}$ & $\begin{array}{l}1950 \\
1780\end{array}$ & $\begin{array}{l}2200 \\
2200\end{array}$ & $\begin{array}{l}3120 \\
3280\end{array}$ \\
\hline & Average & 1860 & 2200 & 3200 \\
\hline $\begin{array}{l}15^{\circ} \mathrm{F} 24 \mathrm{hr} \text { after } \\
\text { casting }\end{array}$ & $\begin{array}{l}1 \\
2\end{array}$ & $\begin{array}{l}2100 \\
2040\end{array}$ & $\begin{array}{l}3350 \\
2770 \\
\end{array}$ & $\begin{array}{l}3340 \\
3220\end{array}$ \\
\hline & Average & 2070 & 3060 & 3280 \\
\hline $\begin{array}{l}70^{\circ} \pm 3^{\circ} \mathrm{F} \text { and } \\
90-100 \% \text { humidity }\end{array}$ & $\begin{array}{l}1 \\
2\end{array}$ & $\begin{array}{l}3060 \\
3280 \\
\end{array}$ & $\begin{array}{l}\mathbf{3 2 7 0} \\
\mathbf{3 1 3 0} \\
\end{array}$ & $\begin{array}{l}3040 \\
3540\end{array}$ \\
\hline & Average & 3170 & 3200 & $=3290$ \\
\hline
\end{tabular}

\section{Effect of specimen thickness on heat of hydration and strength}

As discussed previously, one criterion for the placement of concrete in arctic regions is that the hydration heat should not melt the subgrade or permafrost. To investigate the temperature buildup in the concrete caused by hydration and the transfer of heat to the subgrade, four test slabs were cast. The slabs were $20 \times 20$ in. square, with one being 3 in. thick, two 6 in. thick, and one 12 in. thick. Four inches of sand was compacted in the bottom of each mold to represent the subgrade, except for one mold which had no sand base. The molds and sand were brought to $15^{\circ} \mathrm{F}$ prior to placing concrete in them. A thermocouple for monitoring temperature was placed in the vertical and horizontal center of each concrete slab. A second thermocouple was placed at the depth of $1 \mathrm{in}$. in the sand layer beneath the concrete slab and at the same horizontal location.

The storage and testing procedure was as follows:

1. One $20-20-\times 6$-in - test slab was placed at $70^{\circ} \pm 3^{\circ} \mathrm{F}$ and 90 to $100 \%$ relative humidity immediately after casting. This mold did not have a sand base.

2. All other slabs were placed at $15^{\circ} \mathrm{F}$ immediately after casting.

3. The temperature in both the concrete and the sand beneath was recorded until the ambient temperature was reached for all slabs exposed at $15^{\circ} \mathrm{F}$, but measurements up to the ambient temperature were made only in the concrete for the slab exposed at $70^{\circ} \pm 3^{\circ} \mathrm{F}$.

4. At seven days age the molds were stripped and the slabs sawed into cubes. The 12-in.-thick slab was sawed horizontally into two 6-in.-thick slabs, which were in turn sawed into 6- $\times 6$ $x$ 6-in. cubes. The 6-in. slabs were also sawed into 6- $\times 6 \times 6$-in. cubes, and the 3 -in. slab was sawed into 3- $\times 3-\times 3$-in. cubes. Cubes were broken in compression at 8 and 28 days age.

Compressive strength results of cubes sawed from the slabs are shown in Table X and Figure 2. Compressive strengths were greater in the thicker slabs. The strengths of specimens from the bottom 6 in. of the 12 -in. slab exposed at $15^{\circ} \mathrm{F}$ were greater at 8 and 28 days than specimens from the 6 -in. slab exposed at $70^{\circ} \pm 3^{\circ} \mathrm{F}$; however, strengths of specimens from the top 6 in. of the 12 -in. slab were slightly lower than the 28 -day old specimens exposed to $70^{\circ} \pm 3^{\circ} \mathrm{F}$. 


\begin{tabular}{|c|c|c|}
\hline Line & Slab Thickness( inches) & Slorage Temp ( ${ }^{\circ} \mathrm{F}$ ) \\
\hline A & 12 (bollom) & 15 \\
B & 6 & 70 \\
C & 12 (top) & 15 \\
D & 6 & 15 \\
E & 3 & 15 \\
\hline
\end{tabular}

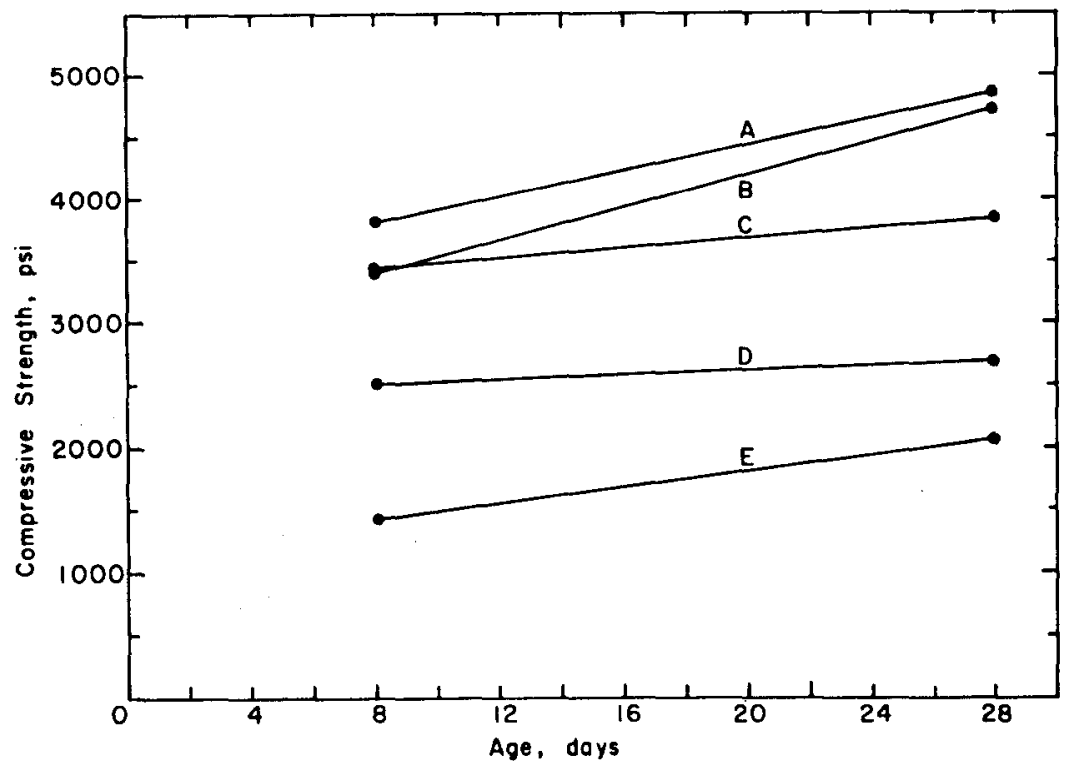

Figure 2. Effect of slab thickness on compressive strength.

Table X. Compressive strength of cubes sawed from temperature study concrete slabs.

\begin{tabular}{|c|c|c|c|c|}
\hline \multirow{2}{*}{$\begin{array}{c}\text { Slab } \\
\text { thickness } \\
\text { (in.) }\end{array}$} & \multirow{2}{*}{$\begin{array}{c}\text { Storage } \\
\text { condition }\end{array}$} & \multirow{2}{*}{$\begin{array}{c}\text { Specimen } \\
\text { no. }\end{array}$} & \multicolumn{2}{|c|}{$\begin{array}{l}\text { Compressive } \\
\text { strength (psi) }\end{array}$} \\
\hline & & & 8 days & 28 days \\
\hline \multirow[t]{4}{*}{3} & $15^{\circ} \mathrm{F}$ immediately & 1 & 950 & 2100 \\
\hline & after casting & 2 & 1550 & 1620 \\
\hline & & $\mathbf{3}$ & 1790 & 2460 \\
\hline & & Average & 1430 & 2060 \\
\hline \multirow[t]{3}{*}{6} & $15^{\circ} \mathrm{F}$ immediately & 1 & 2550 & 2520 \\
\hline & after casting & 2 & 2470 & 2850 \\
\hline & & Average & 2510 & 2680 \\
\hline \multirow[t]{6}{*}{12} & $15^{\circ} \mathrm{F}$ immediately & $1 \mathrm{~T} *$ & 3940 & 4290 \\
\hline & after casting & $2 T^{*}$ & 2950 & 3390 \\
\hline & & Average & 3440 & 3840 \\
\hline & & $1 \mathrm{B \dagger}$ & 3570 & 5040 \\
\hline & & $2 \mathrm{~B}+$ & 3810 & 4630 \\
\hline & & Average & 3810 & 4840 \\
\hline \multirow[t]{3}{*}{6} & $70^{\circ} \pm 3^{\circ} \mathrm{F}$ and & 1 & 3040 & 4170 \\
\hline & $90-100 \%$ humidity & 2 & 3760 & 5280 \\
\hline & & Average & 3400 & 4730 \\
\hline
\end{tabular}

- Sawed from top 6 in. of slab.

t Sawed from bottom 6 in. of slab. 
Table XI. Temperature rise in concrete slabs of various thicknesses and transfer of temperature to a sand base.

\begin{tabular}{|c|c|c|c|c|c|c|c|}
\hline \multirow[b]{3}{*}{ Hr:min } & \multirow{3}{*}{$\begin{array}{l}6 \text { in. slab } \\
70^{\circ} \pm 3^{\circ} \mathrm{F} \\
\text { storage }\end{array}$} & \multicolumn{6}{|c|}{ Temperature, ${ }^{\circ} \mathrm{F}$} \\
\hline & & \multicolumn{2}{|c|}{$\begin{array}{c}6-i n \text { slab } \\
15^{\circ} \mathrm{F} \text { storage }\end{array}$} & \multicolumn{2}{|c|}{$\begin{array}{c}12-\text { in. slab } \\
15^{\circ} \mathrm{F} \text { storage }\end{array}$} & \multicolumn{2}{|c|}{$\begin{array}{c}\text { 3-in. slab } \\
15^{\circ} \mathrm{F} \text { storage }\end{array}$} \\
\hline & & Concrete & Sand & Concrete & Sand & Concrete & Sand \\
\hline 0 & 35.0 & 35.0 & 30.0 & 35.0 & 30.0 & 35.0 & 30.0 \\
\hline 20 & 51.0 & 43.0 & 35.0 & 52.5 & 37.0 & 37.0 & 36.0 \\
\hline 40 & 61.0 & 52.0 & 41.5 & 64.0 & 42.0 & 41.5 & 41.0 \\
\hline $1: 00$ & 63.0 & 57.0 & 45.0 & 66.5 & 47.0 & 44.5 & 42.0 \\
\hline $1: 20$ & 64.5 & 58.0 & 47.0 & 68.0 & 49.0 & 46.5 & 42.5 \\
\hline $1: 40$ & 65.5 & 57.5 & 50.0 & 69.0 & 50.5 & 46.0 & 43.0 \\
\hline $2: 20$ & 67.5 & 56.5 & 52.0 & 68.5 & 52.0 & 43.0 & 43.5 \\
\hline $2: 40$ & 68.0 & 55.5 & 51.5 & 68.0 & 53.5 & 40.5 & 43.0 \\
\hline $3: 00$ & 69.0 & 55.0 & 51.0 & 68.0 & 54.5 & 39.0 & 40.0 \\
\hline $3: 20$ & 70.0 & 54.0 & 51.0 & 67.5 & 55.0 & 37.5 & $\mathbf{3 8 . 0}$ \\
\hline $3: 40$ & 70.5 & 53.5 & 50.5 & 67.5 & 56.0 & 37.0 & 38.0 \\
\hline $4: 00$ & 71.0 & 52.5 & 50.5 & 67.0 & 56.0 & 37.0 & 37.0 \\
\hline $4: 20$ & 71.5 & 52.0 & 50.0 & 66.5 & 56.5 & 36.5 & 37.0 \\
\hline $4: 40$ & 72.0 & 51.0 & 49.0 & 66.0 & 56.5 & 35.5 & 36.0 \\
\hline $5: 00$ & 72.5 & 50.5 & 48.5 & 66.0 & 57.0 & 34.5 & 35.5 \\
\hline $6: 00$ & 73.4 & 48.0 & 48.5 & 64.0 & 56.5 & 31.5 & 33.0 \\
\hline $7: 00$ & 74.1 & 45.0 & 46.5 & 61.5 & 56.0 & 30.5 & 31.0 \\
\hline $8: 00$ & 74.6 & 42.5 & 41.5 & 59.5 & 55.0 & 29.0 & 29.5 \\
\hline 9:00 & 75.0 & 40.5 & 40.0 & 57.5 & 53.5 & 28.0 & 28.5 \\
\hline $10: 00$ & 75.1 & 38.5 & 38.0 & 55.0 & 52.5 & 27.0 & 27.0 \\
\hline $11: 00$ & 75.2 & 36.5 & 36.0 & 53.0 & 50.5 & 26.5 & 27.0 \\
\hline $12: 00$ & 75.3 & 35.0 & 34.5 & 51.5 & 49.5 & 26.0 & 26.0 \\
\hline $13: 00$ & 75.5 & 33.5 & 33.0 & 49.0 & 48.0 & 26.0 & 26.0 \\
\hline $14: 00$ & 75.3 & 32.0 & 31.5 & 47.5 & 46.5 & 25.5 & 25.5 \\
\hline $15: 00$ & 75.2 & 31.0 & 30.5 & 46.0 & 45.5 & 25.0 & 25.0 \\
\hline $16: 00$ & 75.1 & 29.5 & 29.0 & 44.5 & 44.0 & 24.0 & 24.0 \\
\hline $17: 00$ & 75.1 & 28.5 & 28.5 & 43.0 & 42.5 & 23.5 & 23.5 \\
\hline $18: 00$ & 75.0 & 28.0 & 27.5 & 42.0 & 41.0 & 23.0 & 23.0 \\
\hline $19: 00$ & 75.0 & 27.5 & 27.0 & 40.5 & 40.5 & 23.0 & 23.0 \\
\hline $20: 00$ & 75.0 & 26.5 & 26.0 & 39.5 & 39.5 & 22.5 & 22.5 \\
\hline $21: 00$ & 75.0 & 26.5 & 26.0 & 38.0 & 38.0 & 22.0 & 22.0 \\
\hline $22: 00$ & 75.0 & 26.0 & 25.5 & 37.5 & 37.5 & 21.5 & 21.5 \\
\hline 23:00 & 75.5 & 26.0 & 25.5 & 37.0 & 36.5 & 21.5 & 21.5 \\
\hline $24: 00$ & 76.0 & 25.5 & 25.0 & 36.0 & 35.0 & 21.0 & 21.0 \\
\hline $25: 00$ & 76.5 & 25.0 & 24.5 & 35.0 & 34.5 & 20.5 & 20.5 \\
\hline $26: 00$ & 77.0 & 24.5 & 24.0 & 34.5 & 33.5 & 20.0 & 20.0 \\
\hline $27: 00$ & 77.0 & 24.0 & 23.5 & 33.0 & 32.5 & 19.0 & 19.0 \\
\hline $28: 00$ & 77.5 & 23.5 & 23.0 & 32.5 & 31.5 & 18.5 & 18.5 \\
\hline $29: 00$ & 78.0 & 23.0 & 22.5 & 32.0 & 31.0 & 18.0 & 18.0 \\
\hline $30: 00$ & 78.5 & 23.0 & 22.5 & 31.0 & 30.5 & 17.5 & 17.5 \\
\hline $31: 00$ & 79.0 & 22.5 & 22.0 & 30.0 & 29.5 & 17.0 & 17.0 \\
\hline $32: 00$ & 79.0 & 22.0 & 21.5 & 29.0 & 28.5 & 16.5 & 16.5 \\
\hline $36: 00$ & 79.5 & 20.0 & 20.0 & 26.0 & 26.0 & 14.5 & 14.5 \\
\hline $42: 00$ & 78.0 & 17.5 & 17.5 & 24.0 & 24.0 & 12.5 & 13.5 \\
\hline $48: 00$ & 75.5 & 16.0 & 16.0 & 21.0 & 21.0 & 13.0 & 13.0 \\
\hline $54: 00$ & 73.5 & 15.0 & 15.0 & 19.0 & 19.0 & 13.0 & 13.0 \\
\hline $60: 00$ & $=71.5$ & 14.0 & 14.0 & 17.5 & 17.5 & 12.0 & 12.0 \\
\hline $66: 00$ & 70.5 & 13.0 & 13.0 & 16.5 & 16.5 & 12.0 & 12.0 \\
\hline $72: 00$ & 70.0 & 13.0 & 13.0 & 15.5 & 15.5 & 12.0 & 12.0 \\
\hline 78:00 & 69.5 & 13.0 & 13.0 & 15.0 & 15.0 & 12.0 & 12.0 \\
\hline $84: 00$ & 69.0 & 13.5 & 13.5 & 14.0 & 14.0 & 13.0 & 13.0 \\
\hline $90: 00$ & 68.5 & 13.0 & 13.0 & 14.0 & 14.0 & 13.0 & 13.0 \\
\hline 96:00 & 68.5 & 13.0 & 13.0 & 13.5 & 13.5 & 13.0 & 13.0 \\
\hline
\end{tabular}

The results of the temperature measurements in the slabs shown in Table XI and Figures 3-6 can be summarized as follows:

1. The temperature in a 6 -in. slab, with all materials at $35^{\circ} \mathrm{F}$ prior to mixing and with an exposure temperature of $70^{\circ} \pm 3^{\circ} \mathrm{F}$, rose to approximately $70^{\circ} \mathrm{F}$ in 12 hours and peaked at $79.5^{\circ} \mathrm{F}$ in 36 hours. The slab temperature then returned to ambient in approximately 72 hours. 


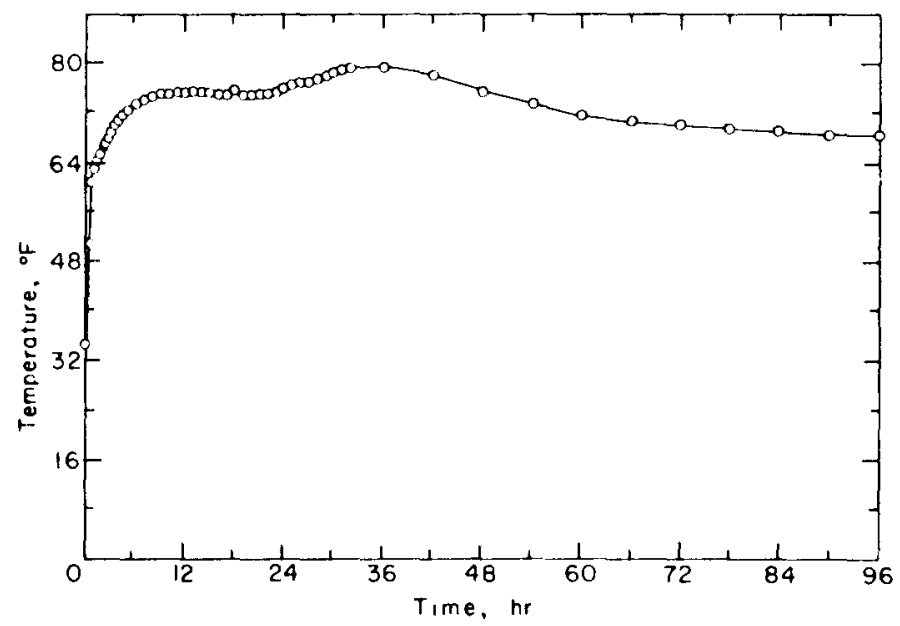

Figure 3. Temperature rise in 6-in. slab exposed at $70^{\circ} \pm 3^{\circ} \mathrm{F}$.

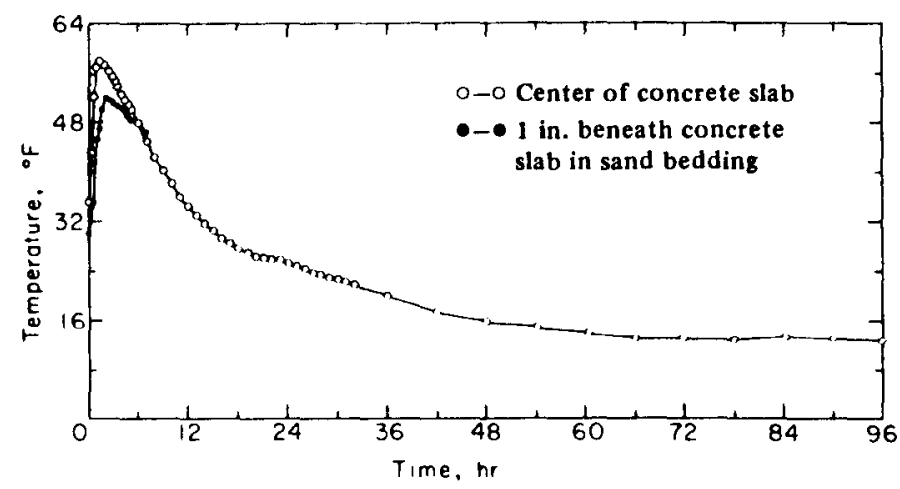

Figure 4. Temperature rise in 6-in. slab and sand base exposed at $15^{\circ} \mathrm{F}$.

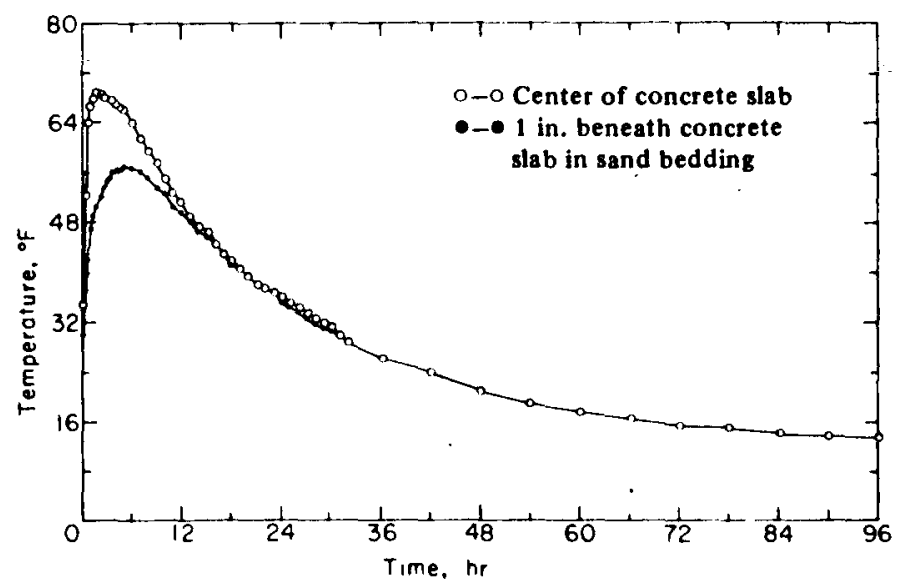

Figure 5. Temperature rise in 12-in. slab and sand base exposed at $15^{\circ} \mathrm{F}$. 


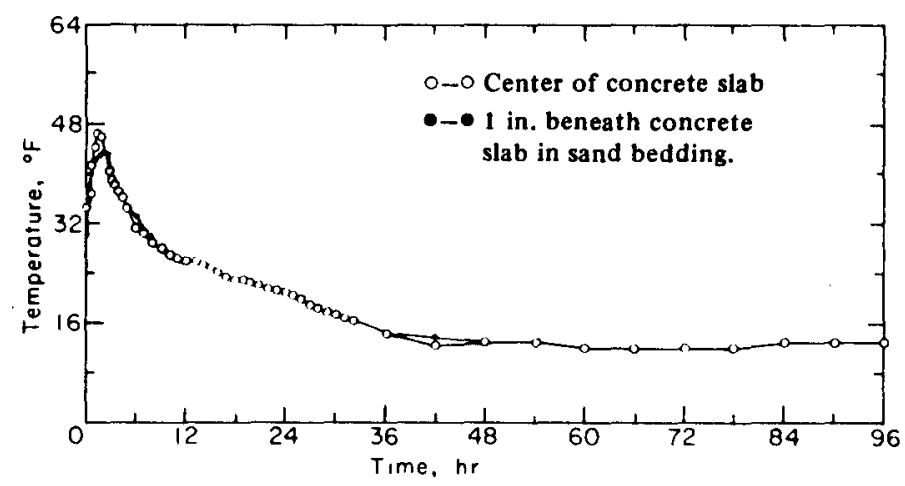

Figure 6. Temperature rise in a 3-in. slab and in sand base exposed at $15^{\circ} \mathrm{F}$.

2. The temperature in the 6 -in. slab exposed at $15^{\circ} \mathrm{F}$ immediately after mixing peaked at $58^{\circ} \mathrm{F}$ at 1 hour 20 minutes. Ambient temperature was reached in approximately 38 hours. The temperature in the sand base peaked at $52^{\circ} \mathrm{F}$ at 2 hours 20 minutes and reached the slab temperature at 6 hours.

3. The temperature in a 12 -in.-thick slab exposed at $15^{\circ} \mathrm{F}$ peaked at $69^{\circ} \mathrm{F}$ at 1 hour 40 minutes and reached ambient in about 84 hours. The temperature in the sand base underneath peaked at $57^{\circ} \mathrm{F}$ at five hours and reached the temperature of the slab at approximately 15 hours.

4. The temperature in the 3 -in. slab peaked at $46.5^{\circ} \mathrm{F}$ at 1 hour 20 minutes and reached ambient at about 36 hours. The temperature in the sand base peaked at $43.5^{\circ} \mathrm{F}$ at 2 hours $20 \mathrm{~min}$ utes and also reached the temperature of the slab at that time.

\section{Effect of retarder and water/cement ratio on concrete containing regulated-set cement}

Three batches of concrete were mixed. All materials were at $35^{\circ} \mathrm{F}$ immediately prior to mixing and were exposed at different temperatures afterward. Sixteen $6 \cdot \times 6-\times 6$-in. cubes were cast from each batch. The three batches were as follows:

1. Batch 1. The same mixture was used as in the Effect of Age When Frozen and Effect of Specimen Thickness phases, except this was a $3-\mathrm{ft}^{3}$-mixture. This mixture had a slump of $2 \frac{1}{2}$ in.

2. Batch 2. The same as Batch 1 except that, while the water/cement ratio was held the same as Batch 1, the water and cement content was increased to obtain a slump of $4 \frac{1}{2} \mathrm{in}$. The cement was increased $25 \mathrm{lb} / \mathrm{yd}^{3}$ with a corresponding increase in the water.

3. Batch 3. All mixture weights were the same as Batch 1 except a retarder (commercial grade citric acid) was added in the amount of $454 \mathrm{~g} / \mathrm{yd}^{3}$. Earlier tests had indicated that this amount would delay the initial setting time of this regulated-set cement mixture to 1 hour 12 minutes and final set to 1 hour 21 minutes. The slump was $5 \frac{1}{4}$ in. and air content $9.5 \%$.

The effects of retarder and water/content ratio on reg-set cement are shown in Figures 7 and 8 and in Table XII. 

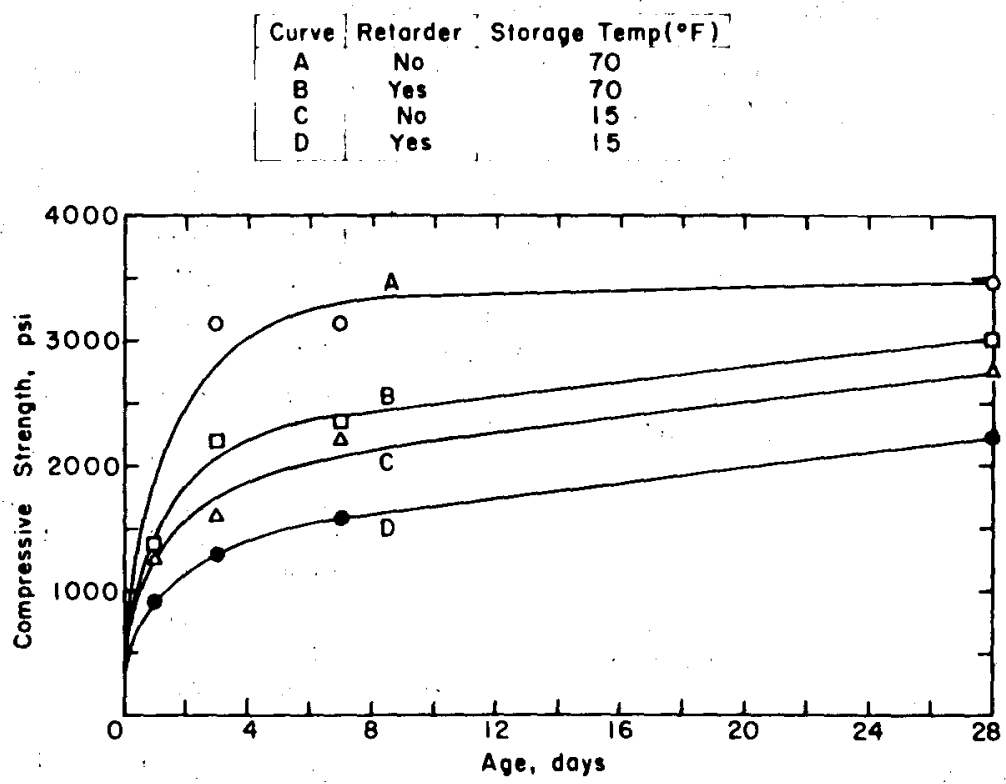

Figure 7. Effect of storage temperature and retarder.

\begin{tabular}{|c|c|c|}
\hline Curve & Slump(inches) & Storoge \\
\hline A & 2 & 70 \\
B & 4.5 & 70 \\
C & 2 & 15 \\
D & 4.5 & 15 \\
\hline
\end{tabular}

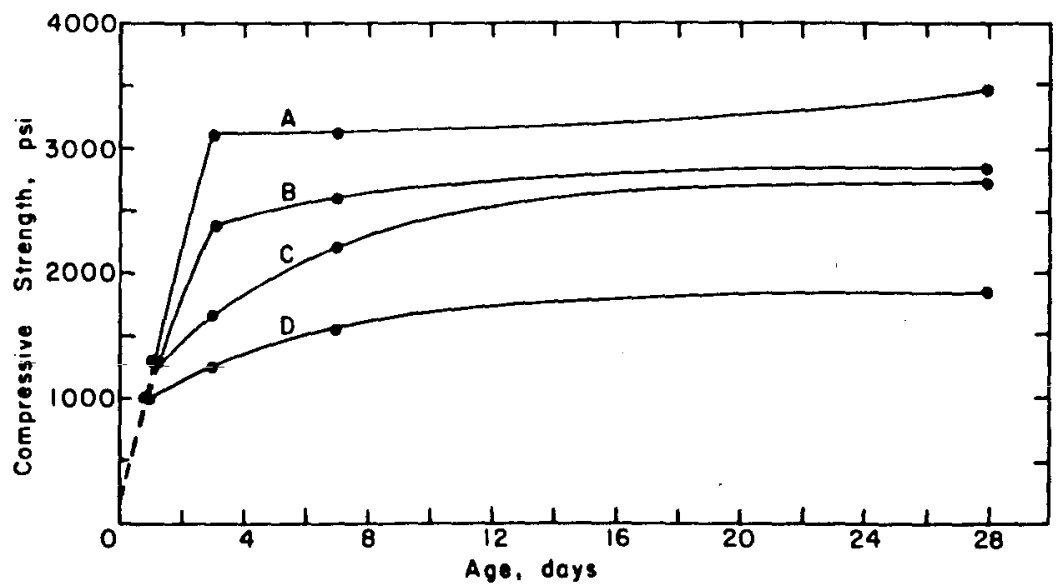

Figure 8. Effect of storage temperature and slump.

The results indicate the following:

1. The addition of retarder reduces the compressive strength of concrete cubes through 28 days agc. This is true both for cubes stored at $70^{\circ} \mathrm{F}$ and at $15^{\circ} \mathrm{F}$. The reduction was in the order of 13 to $19 \%$. The addition of the retarder while holding a constant water/cement ratio increased the slump from $2 \frac{1}{2}$ in. (no retarder) to $5 \frac{1}{4}$ in. It could be surmised that strengths would not have been reduced, at least to the extent noted, if the water content in the retarded mixture had been reduced to obtain a slump of $2 \frac{1}{2}$ in. 
Table XII. Effect of retarder and slump on reg-set cement.

\begin{tabular}{|c|c|c|c|c|c|c|c|}
\hline \multirow{2}{*}{$\begin{array}{l}\text { Batch } \\
\text { no. }\end{array}$} & \multirow[b]{2}{*}{ Variable } & \multirow{2}{*}{$\begin{array}{c}\text { Storage } \\
\text { condition } \\
\end{array}$} & \multirow{2}{*}{$\begin{array}{c}\text { Specimen } \\
\text { no. }\end{array}$} & \multicolumn{4}{|c|}{ Compressive strength, pst } \\
\hline & & & & $1 d a y$ & 3 days & 7 days & 28 days \\
\hline \multirow[t]{2}{*}{1} & Slump 2 in. & $\begin{array}{c}70 \pm 3^{\circ} \mathrm{F} \text { and } \\
90-100 \% \text { humidity }\end{array}$ & $\begin{array}{l}1 \\
2\end{array}$ & $\begin{array}{l}1240 \\
1220 \\
\end{array}$ & $\begin{array}{l}3100 \\
3170 \\
\end{array}$ & $\begin{array}{l}3110 \\
3200 \\
\end{array}$ & $\begin{array}{l}\mathbf{3 1 7 0} \\
\mathbf{3 8 2 0} \\
\end{array}$ \\
\hline & & & Average & 1230 & 3130 & 3150 & $\mathbf{3 4 7 0}$ \\
\hline \multirow[t]{2}{*}{1} & Slump 2 in. & $15^{\circ}$ & $\begin{array}{l}1 \\
2\end{array}$ & $\begin{array}{l}1170 \\
1310 \\
\end{array}$ & $\begin{array}{l}1570 \\
1630 \\
\end{array}$ & $\begin{array}{l}2130 \\
2290 \\
\end{array}$ & $\begin{array}{l}2690 \\
2810 \\
\end{array}$ \\
\hline & & & Average & 1240 & 1600 & 2210 & 2750 \\
\hline \multirow[t]{2}{*}{2} & Slump $4 \frac{1 / 2}{\text { in. }}$. & $\begin{array}{c}70 \pm 3^{\circ} \mathrm{F} \text { and } \\
90-100 \% \text { humidity }\end{array}$ & $\begin{array}{l}1 \\
2\end{array}$ & $\begin{array}{l}1050 \\
1120 \\
\end{array}$ & $\begin{array}{l}2460 \\
2270 \\
\end{array}$ & $\begin{array}{l}2730 \\
2470 \\
\end{array}$ & $\begin{array}{l}2710 \\
3000 \\
\end{array}$ \\
\hline & & & Average & 1090 & $237 n$ & 2600 & 2850 \\
\hline \multirow[t]{2}{*}{2} & Slump $4 \frac{132}{2}$ in. & $15^{\circ}$ & $\begin{array}{l}1 \\
2\end{array}$ & $\begin{array}{l}1010 \\
1060 \\
\end{array}$ & $\begin{array}{l}1170 \\
1190 \\
\end{array}$ & $\begin{array}{l}1590 \\
1580 \\
\end{array}$ & $\begin{array}{r}1820 \\
1870 \\
\end{array}$ \\
\hline & & & Average & 1040 & 1180 & 1580 & 1840 \\
\hline \multirow[t]{2}{*}{3} & $\begin{array}{l}\text { Retarder } \\
\text { (citric acid) }\end{array}$ & $\begin{array}{c}70 \pm 3^{\circ} \mathrm{F} \text { and } \\
90-100 \% \text { humidity }\end{array}$ & $\begin{array}{l}1 \\
2\end{array}$ & $\begin{array}{l}1420 \\
1320 \\
\end{array}$ & $\begin{array}{l}2290 \\
2130 \\
\end{array}$ & $\begin{array}{l}2440 \\
2260 \\
\end{array}$ & $\begin{array}{l}3030 \\
3010 \\
\end{array}$ \\
\hline & Slump $5 \frac{1}{4}$ in. & & Average & 1370 & 2210 & 2350 & 3020 \\
\hline \multirow[t]{2}{*}{3} & $\begin{array}{l}\text { Retarder } \\
\text { (citric acid) }\end{array}$ & $15^{\circ}$ & $\begin{array}{l}1 \\
2\end{array}$ & $\begin{array}{l}900 \\
960 \\
\end{array}$ & $\begin{array}{l}1300 \\
1320 \\
\end{array}$ & $\begin{array}{l}1570 \\
1620 \\
\end{array}$ & $\begin{array}{l}2240 \\
2220 \\
\end{array}$ \\
\hline & Slump $5 \% / 4$ in. & & Average & 930 & 1310 & 1590 & 2230 \\
\hline
\end{tabular}

2. Increasing the slump from $2-$ to $4 \frac{1}{2}$ in. in an unretarded mixture, while holding the water/cement ratio constant, reduced the compressive strength 18 to $29 \%$ at seven days age although the cement content was increased. This was true for specimens exposed at $70 \pm 3^{\circ} \mathrm{F}$ and companion specimens exposed at $15^{\circ} \mathrm{F}$.

\section{CONCLUSION}

The results of this investigation indicate that concrete containing regulated-set cement will gain strength, even when unprotected, when placed at temperatures as low as $15^{\circ} \mathrm{F}$. This is accomplished because the chemical reaction between the cement and water is accelerated and hydration heat is generated-almost-immediately after the mixing of cement and water. This heat generation sustains temperatures within the mixture above freezing long enough for considerable strength buildup.

The following factors affect strength development of concrete containing regulated-set cement when freshly mixed and exposed unprotected at $15^{\circ} \mathrm{F}$.

1. The age of the concrete when placed at $15^{\circ} \mathrm{F}$. The longer the mixture remains above freezing before exposure the greater the subsequent strength gain. The mixtures tested, however, will gain considerable strength even when exposed to $15^{\circ} \mathrm{F}$ immediately after mixing, and when protected as long as an hour after mixing before exposing at $15^{\circ} \mathrm{F}$, will exhibit almost as much strength at 28 days age as specimens exposed at $70^{\circ} \pm 3^{\circ} \mathrm{F}$ for the full time.

2. Thickness of section. The heat development in 3-, 6- and 12-in.-thick slabs exposed at $15^{\circ} \mathrm{F}$ immediately after casting rose to $46.5^{\circ}, 58^{\circ}$ and $69^{\circ} \mathrm{F}$, respectively, in 1 to 2 hours and then dropped off, indicating enough internal heat was generated to sustain hydration. This heat, however, would melt permafrost 1 in. below the slabs. A 12 -in.-thick slab exposed at $15^{\circ} \mathrm{F}$ will obtain almost as much strength as a slab exposed at $70^{\circ} \pm 3^{\circ} \mathrm{F}$ for the full time. 
3. The use of citric acid as a retarder to delay the setting time to one to two hours also decreased the strength of specimens exposed at both $15^{\circ} \mathrm{F}$ and $70^{\circ} \pm 3^{\circ} \mathrm{F}$ by 19 and $13 \%$, respectively. The slump, however, was increased by the retarder. If the water had been reduced to obtain the slump of the unretarded companion mixture, the strength reduction would probably not have been as great.

4. Increasing the slump from 2 to $4 \frac{1}{2}$ in., by increasing the cement content but keeping the water/cement ratio constant, decreased the 7-day strength of specimens exposed both at $70^{\circ} \pm 3^{\circ} \mathrm{F}$ and $15^{\circ} \mathrm{F}$ by 18 and $29 \%$, respectively.

The finding that a 12 -in. slab exposed at $15^{\circ} \mathrm{F}$ will obtain almost as much 8- and 28-day strength as a 6 -in. slab exposed at $70^{\circ} \pm 3^{\circ} \mathrm{F}$ for the full time can possibly be explained as follows. The 12-in. slab contains enough hydrating cement to generate large amounts of heat during hydration. The high heat generation elevates the temperature to a level above the freezing point and creates an en. vironment conducive to continued hydration. This in turn results in an increase in the strength of the concrete. The amount of strength developed apparently parallels that of concrete cured continuously at $70^{\circ} \mathrm{F}$.

\section{RECOMMENDATIONS}

In order to develop sufficient supplemental background and additional criteria necessary for the implementation of regulated-set cement in cold weather concreting operations, it is recommended that the following tasks be undertaken:

1. Synthesis of field experience. Regulated-set cement concrete has been used by the civilian sector for a number of years for activities ranging from highway patching and slipformed tunnel lining to cast-in-place roof decking. Various agencies, organizations, and individuals involved with these applications should be located, contacted, and a compilation of their experiences made. A detailed documentation should be made of selected projects and it should include such information as field construction problems (as related to reg-set use), cracking, durability and cost effectiveness.

2. Prototype evaluation. A concrete test slab of sufficient size and configuration to produce an adequate number of drilled or sawed test specimens for evaluation should be constructed in order to validate the laboratory results contained in this report. For comparison purposes, cast cylinders and beams should also be made. Construction should take place in a location where the ambient temperature is $15^{\circ} \mathrm{F}$ or lower. A suitable location would be at the U.S. Army Cold Regions Research and Engineering Laboratory (CRREL), Hanover, New Hampshire, at a time of the year when these temperatures are prevalent. Both construction procedures and materials behavior could be evaluated by this project.

\section{LITERATURE CITED}

1. ACI Committee 306 (1970) ACI Standard, Recommended practice for cold weather concreting (ACI 306-66). In ACI Manual of Concrete Practice, Part 1. Detroit, Mich.: American Concrete Institute.

2. Burns, C.D. and C.L. Rone (In prep.) Comparative performance of structural layers in pavement systems. In Design, Construction and Behavior Under Load, vol. I, chap. 3. Federal Aviation Agency Report FAARD-73.

3. Canadian Standards Association (1973) Standard A 23.1, Concrete materials and methods of concrete construction. Rexdale, Ontario, Canada. 
4. Corps of Engineers, U.S. Army (1971) Engineering and design, standard practice for concrete. Engineer Manual EM $1110-2-2000$, para. 3.10 and 5.6.

5. Corps of Engineers, U.S. Army (1964) Guide specification for military construction, concrete pavement for roads and airfields. CE-806.01, para. $13 \mathrm{e}$ and $17 \mathrm{~b}$.

6. Corps of Engineers, U.S. Army (1970) Guide specification for military construction, concrete (for building construction). CE 204, para. 16.2 and 26.

7. Corps of Engineers, U.S. Army (1973) Standard guide specifications for concrete, guide specifications, civil works construction. CE 1401.01, para. 12.3, 16.1, 16.2 and 16.4 .

8. Defense Intelligence Agency (1972) Concrete practice in the U.S.S.R. Report E-166 (review of 18 Soviet reports).

9. Department of the Army (1962) Arctic construction. TM 5-349.

10. Fulwider, C.W. and J.H. Stearman (1968) A bibliography on winter construction, 1940-1967. U.S. Army Cold Regions Research and Engineering Laboratory (USA CRREL) Special Report 83. AD 675415.

11. Havers, J.A. and R.M. Morgan (1972) Literature survey of cold weather construction practices: USA CRREL Special Report 172 . AD 745395.

12. Kaplar, C.W. and R.M. Metrish (1974) Bibliography on winter construction, 1967-1971. USA CRREL Special Report 204. AD 778742.

13. Lea, F.M. (1971) The chemistry of cement and concrete. New York: Chemical Publishing Company, 3rd edition, p. 294.

14. Lerch, W, and C.L. Ford (1948) Long-time study in cement performance in concrete. In Chemical and physical tests of the cements. Journal of the A merican Concrete Institute, vol. 44, chap. 3, p. 743.795.

19. Mustard, J.N. (1972) Winter curing of concrete as related to the new Canadian standard. In Behavior of Concrete Under Temperature Extremes. Detroit, Mich.: American Concrete Institute, SP 39.4, ACI Special Publication 39.

16. RILEM (1963) Recommendations for winter concreting. RILEM Winter Construction Committee, Bulletin no. 21 , p. 1-11.

17. RILEM (1956) Proceedings, Winter Concreting Theory and Practice Symposium. Danish National Institute of Building Research, Copenhagen (38 papers with discussions and conclusions).

18. Robson, T.D. (1962) High-alumina cements and concretes. New York: John Wiley \& Sons, Inc., p. 56 and 57.

19. Sizov, V.N. (1961) Construction under winter conditions, 4th ed. (English translation). USA CRREL Draft Translation 69.

20. Voellmy, A. (1956) High concrete quality in cold weather. In (RILEM) Proceedings, Winter Concreting Theory and Practice Symposium. Danish National Institute of Building Research, Copenlagen.

21. Yoakem, D. (1966) A survey of winter construction practices; earthwork, concrete and asphalt. USA CRREL Special Report 76. AD 801626. 


\section{APPENDIX: RECOMMENDATIONS FOR REMOVAL OF FORMS AND SHORES AT LOW TEMPERATURES \\ (From ACI Manual of Concrete Practice, Part 1 1.)}

(Copyright 1970, reprinted by permission)

\section{TABLE 5.I.7 - DURATION OF RECOMMENDED PROTECTION OR PERCENT OF STRENGTH REQUIRED, FOR SAFE FINAL REMOVAL OF FORMS AND SHORES, FOR DIFFERENT COLD WEATHER TEMPERATURE}

Probable outside mean daily air temperature after period of protection*

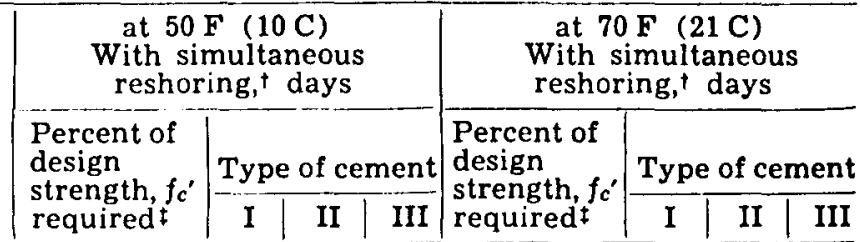

Field cured test specimens need not be required to confirm the following lengths of protection:

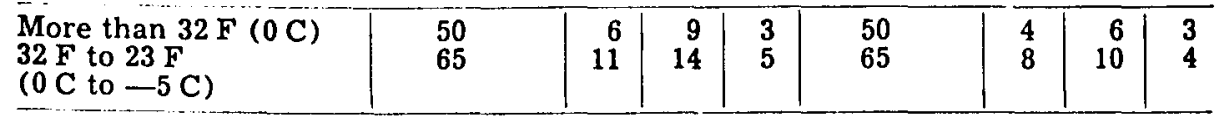

The following lengths of protection are to be used when field cured test specimens were inadvertently not made to confirm sufficiency of protection to produce safe levels of strength development: .

\begin{tabular}{l|l|l|l|l|l|l|l|l}
\hline $23 \mathrm{~F}$ to $16 \mathrm{~F}$ & 85 & 21 & 28 & 16 & 85 & 16 & 18 & 12 \\
$(-5 \mathrm{C}$ to $-9 \mathrm{C})$ & 95 & 29 & 35 & 26 & 95 & 23 & 24 & 20 \\
\hline
\end{tabular}

- From available 5-day and longer forecasts.

+Simultaneous reshorng means a construction method of removing the horizontal floor or roof forms with their supporting shores in a partial area of a panel and immediately installing adequate reshores in the area where forms have been stripped. During this operation, the remainder of the panel shall be continuously supported by shores or reshores. †As demonstrated from a suitable number of acceptably representative job-cured and exposed test specimens.

CAUTION: 1. Without careful simultaneous reshoring, it is extremely hazardous in freezing weather to remove shores even temporarily before suitable tests show conclusively that the specified strength has been obtained.

2. The data in this table were derived from concretes displaying strength of 3000 to 5000 psi $(210$ to $350 \mathrm{~kg}$ per sq $\mathrm{cm})$ after 28 days of curing at $70 \pm 3 \mathrm{~F}(21 \pm 1,67 \mathrm{C})$. This $28-\mathrm{day}$ strength for each type of cement was considered as 100 percent in determining the time to reach various percents of this strength with $50 \mathrm{~F}(10 \mathrm{C})$ and with $70 \mathrm{~F}$ (21 C) curing. Necessarily these values are only approximate and average. Specific values with job materials and mixes should be obtained.

NOTE: Tests indicate that concrete with some Type C or E admixtures (ASTM C 494) may attain required strength in less time than with either Type III cement or an extra sack of cement; see Section 6.3. Use of additional cement and other means of reducing the number of days of protection are discussed in Section 5.7. Tests should be made first with whatever strength-accelerating materials or methods are proposed, to be sure that anticipated ac celeration will be obtained. 
In accordance with ITR $70-2-3$, paragraph $6 c(1)(b)$, dated 15 Pebruary 1973, a facoimile catalog card in Libraxy of Congress formst 18 reproduced below.

Houston, Billy Joe

Cold weather construction materlals; Part 1: Regulated-set cement for cold weather concreting, by Billy J. Houston [ and George C. Hoff. Vicksburg, U. S. Army Englneer Waterways Experiment Station, 1975.

23 p. 11lus. $27 \mathrm{~cm}$. (U. S. Waterways Experiment Station. Miscellaneous paper $\mathrm{C}-75-11$, Part 1)

Prepared for office, Chief of Engineers, U. S. Army, Washington, D. C., under DA Project 4K078012AAM1, Task 00, Work Unit 004.

U. S. Army Cold Regions Research and Engineering Laboratory, Hanover, N. H. Special report 245.

Literature cited: p. 21-22.

1. Cold regions. 2. Construction. 3. Regulated-set concrete. I. Hoff, George C., Joint author. II. U. S. Army. Corpsof Engineers. III. U. S. Army Cold Regions Research and Engineering Laboratory, Hanover, N. H. (Series: U. S. Waterways Experiment Station, Vicksburg, Miss. Miscellaneous paper C-75-11, Part 1)

TA7.W34m no.C-75-11 Part 1 